\title{
مفهوم التنمية في فكر مالك بن نبي
}

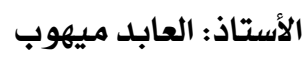

كلية الآداب و اللغات و العلوم الاجتماعية و الانسانية،

قسم العلوم الإجتماعية ، جامعة زيان عاشور الجلفة، الجزائر

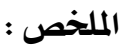

تعتبر التنمية عملية تغيير شاملة، فهى موجهة و معقدة، و تضم كافة

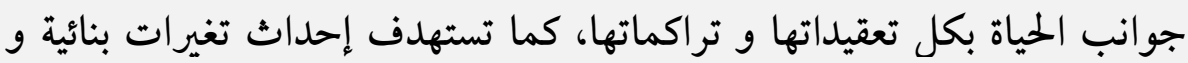

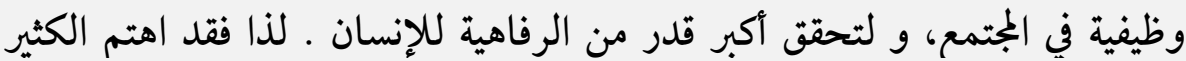

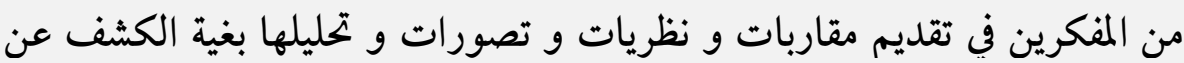

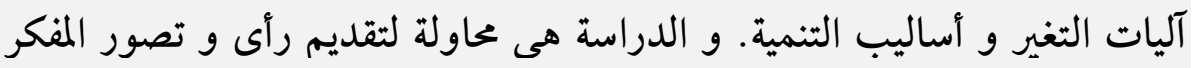

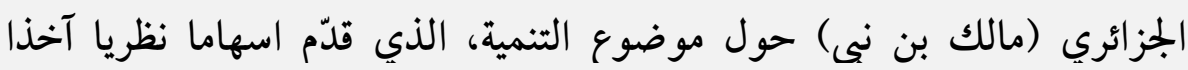
بعين الإعتبار فكرة الحضارة منطلقا من فكرة الإنسان نفسه قبل كل شئ شيء.

\section{Abstract:}

In view of the fact that development is a comprehensive, guided and complicated operation of change. It contains all the living sides, with its complixity and its accumulation. It aims at creation of constructional and functional change in the society, and to realize a very important of welfare for the men. Therfore many thinkers pay attention to present approachers, theories and conceptions with their analysis in order to discover the machinaries of change and ways of development .

This study is an attempt for presenting Malek Ben Nabi's opinion and his conception about the development. Who gives a theoritical contribution and takes into considiration the idea of civilisation, and starts from man himself before all. 


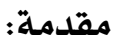

يممع أغلب المنظرين في علم الاجتماع و الاقتصاد على أن التنمية هي

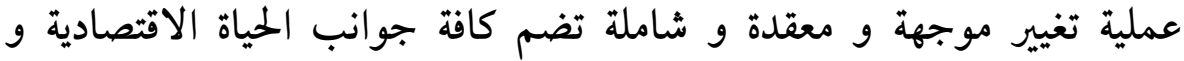

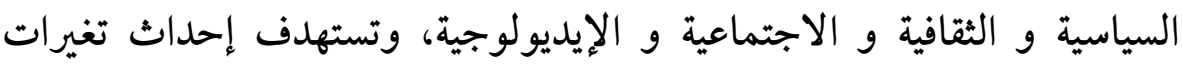

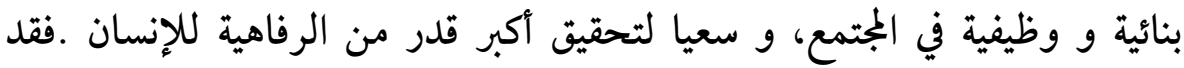

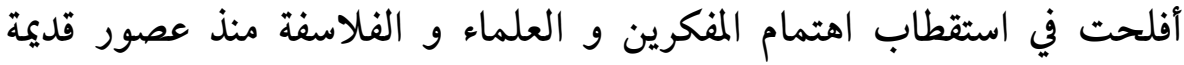
لدراستها و تحليلها بهدف الكشف عن آليات التغير و أساليب التنمية. و كانت التئية

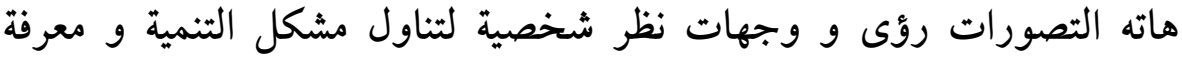

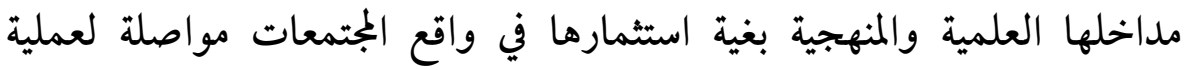
التقدم و التطور أو استنهاضا للو اقع المتخلف.

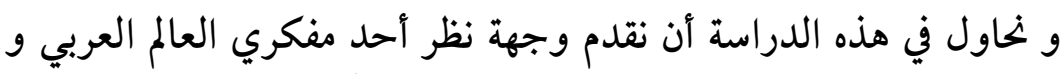

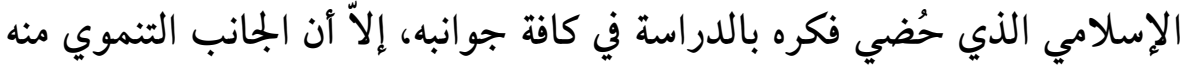

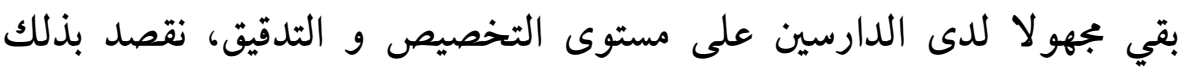

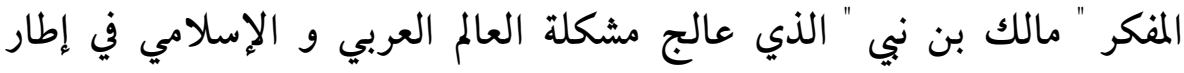

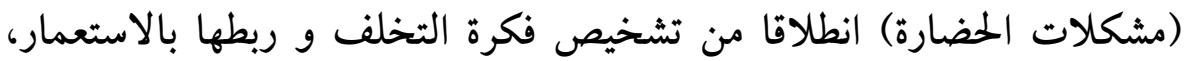

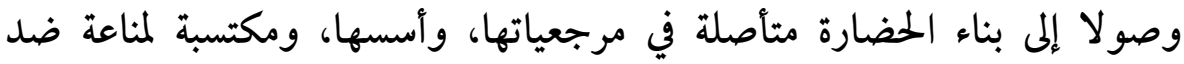

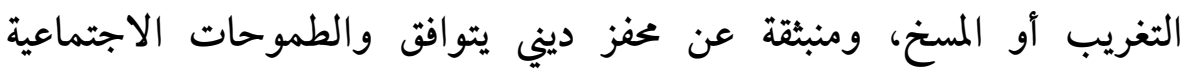

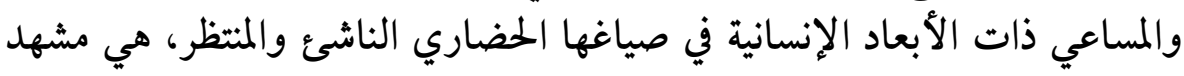

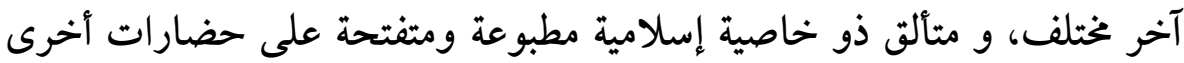

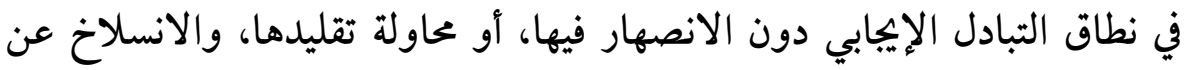

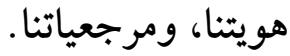

حاول هذه الدراسة أن تجيب عن التساؤلات التالية: 1 ـ ماهي أسباب التخلف و مظاهره ؟ 
2 ـ ماهي مقومات التنمية في فكر مالك بن نبي و ركائزها ؟ 3 ـ ماهي رهانات التنمية عند مالك بن نبي ؟ 1. أسباب التخلف في فكر مالك بن ني: تحاول طائفة من الباحثين معالجة قضايا

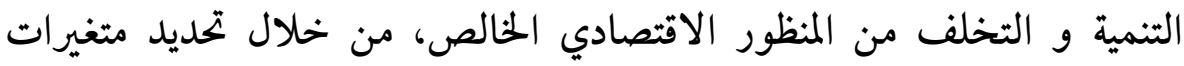

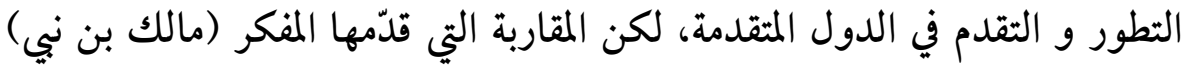
في هذا الموضوع أضافت إلى الطرح التي قدّمته نظرية التنمية في العالم المتقدم التي

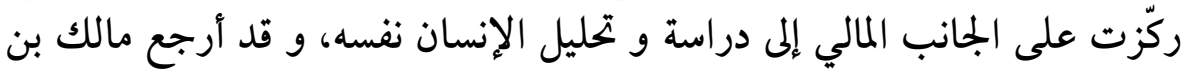
نبي أسباب التخلف إلى العوامل التالية : 1.1: القابلية للاستعمار: أشار مالك بن نبي إلى مفهوم "القابلية للاستعمار" كمفهوم

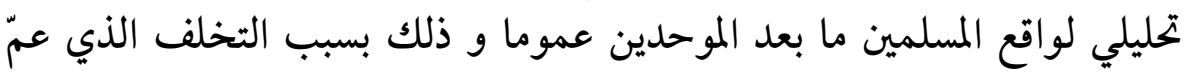

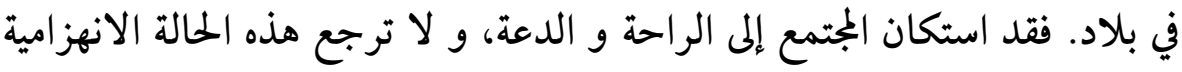

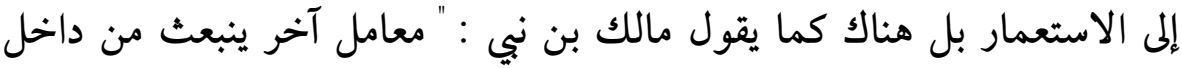

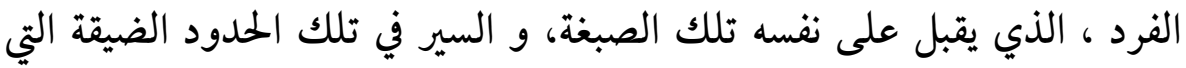

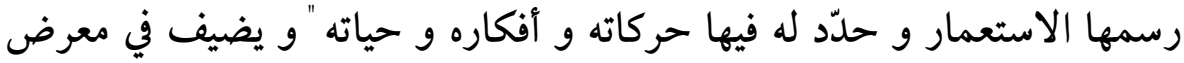

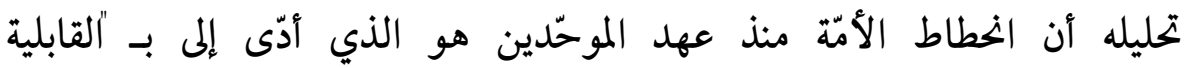

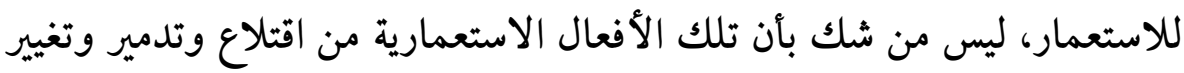

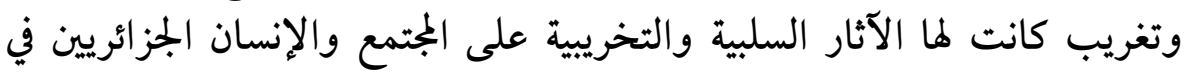

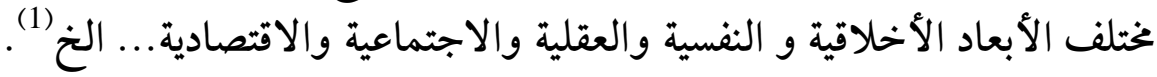
2.1 عدم الفعالية: وكان من نتائج هذا الانفصام الأخلاقي ، أن المسلم يحمل

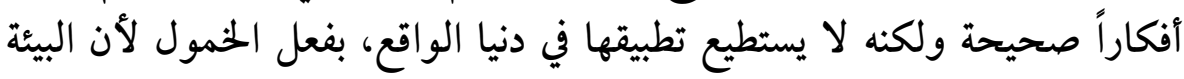

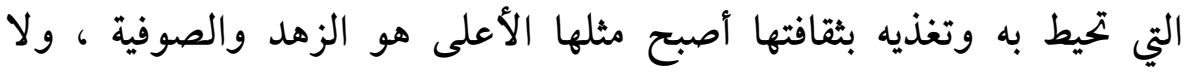

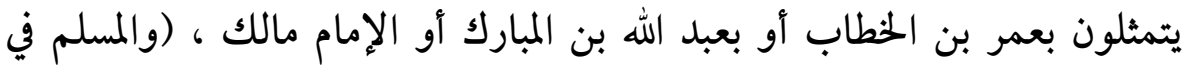

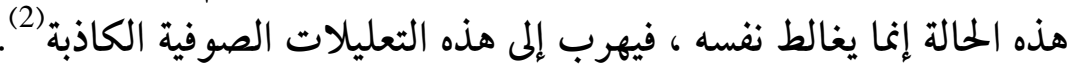


وفي المقابل، نجد عند الغربيين أفكاراً قد لا تثبت أمام النقد الموجه لها ولكنهم

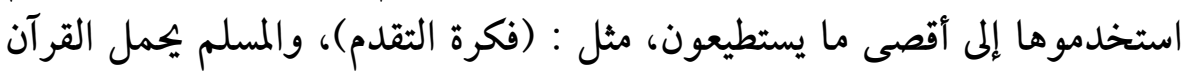

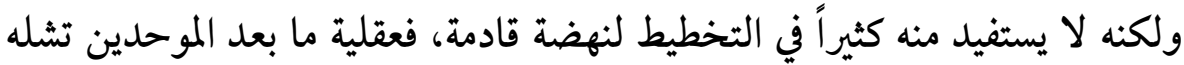

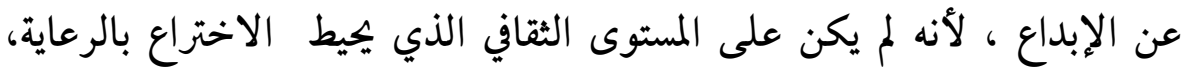

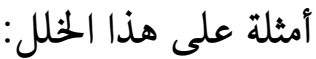

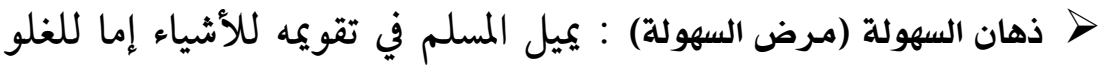

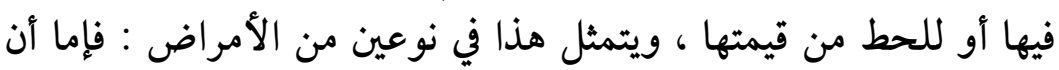

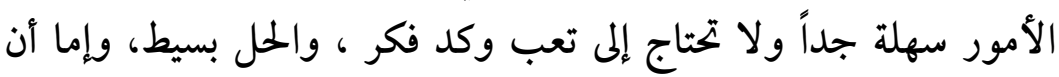

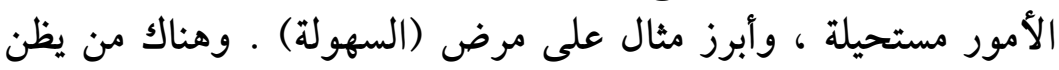

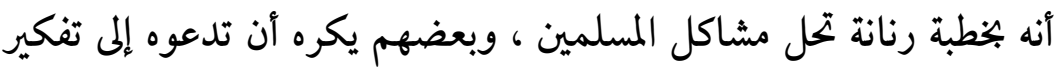

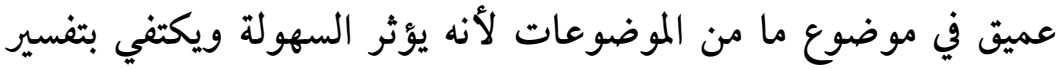

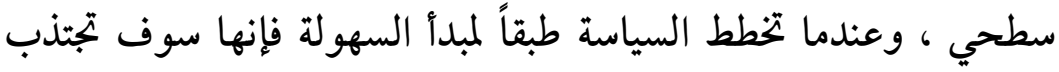

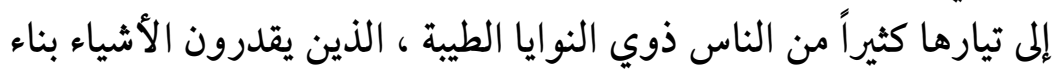

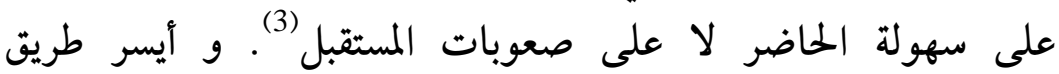

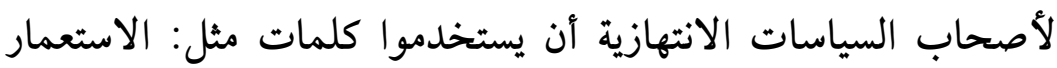

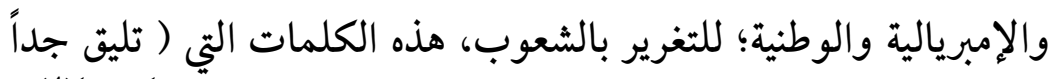
لتشحيم المنحدر حتى يكون الانزلاق عليه نحو السهولة ميسوراً جداً (4).

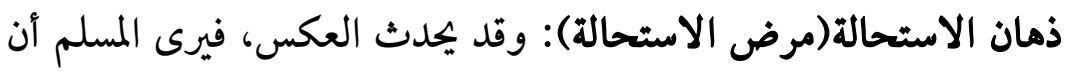

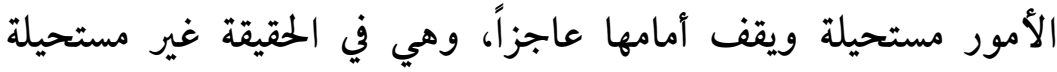

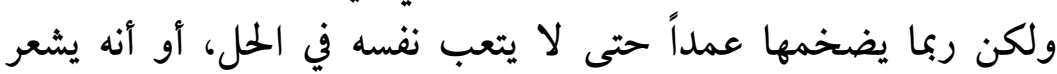

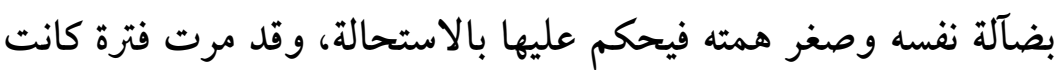

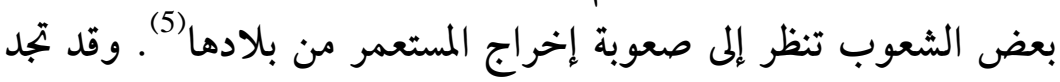

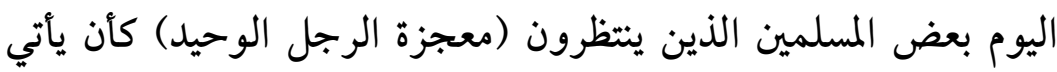


صلاح الدين آخر ليوحد المسلمين من جديد ، ويعتقدون استحالة أية محاولة لاستئناف حياة إسلامية . لماتل

3.1 عدم توازن آليات التبادل التجاري: تعمل الدول الرأسمالية على استغلال

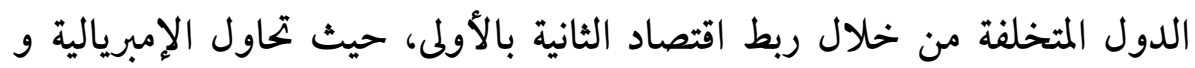

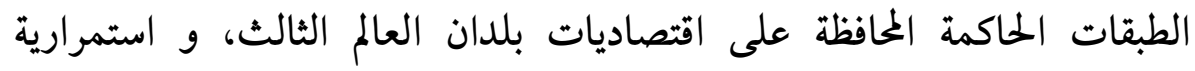

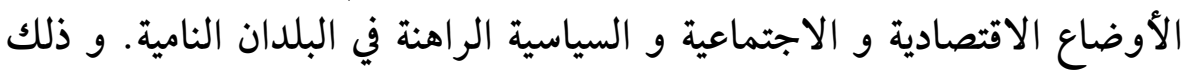

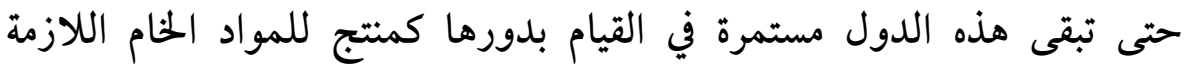

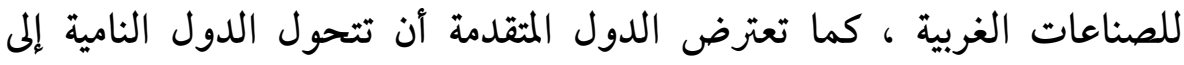

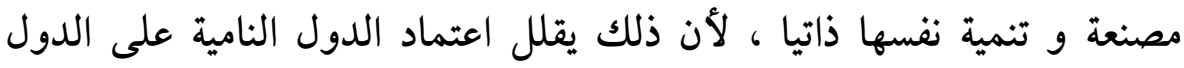

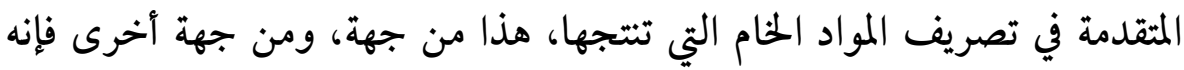

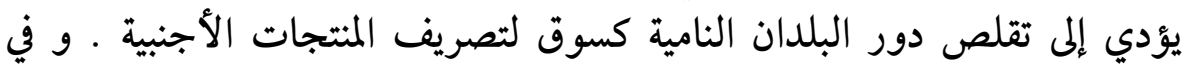

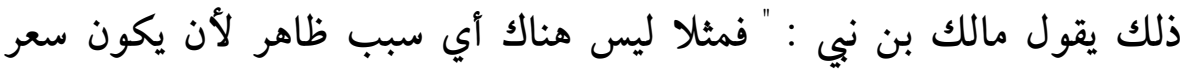

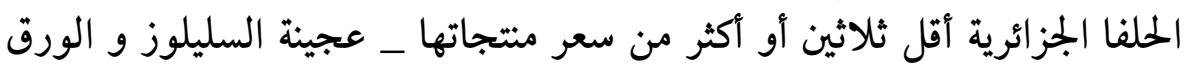

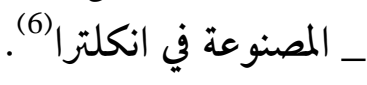

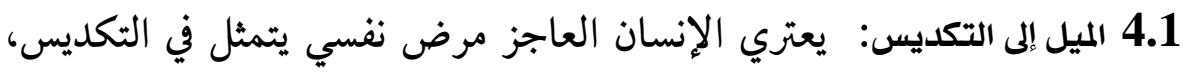

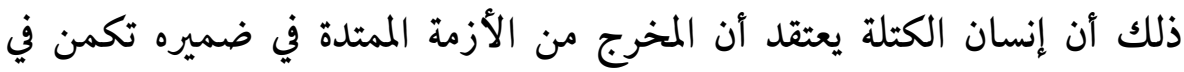

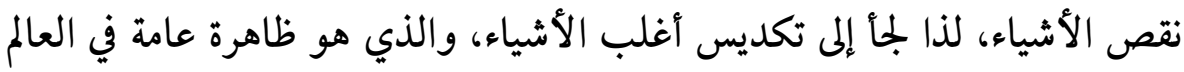

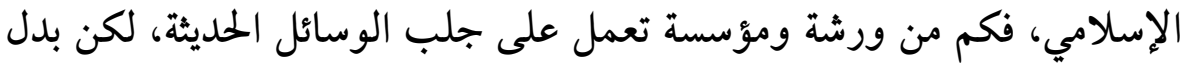

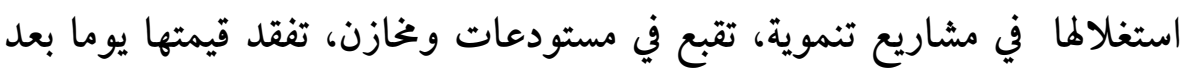

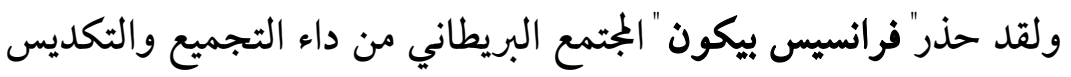

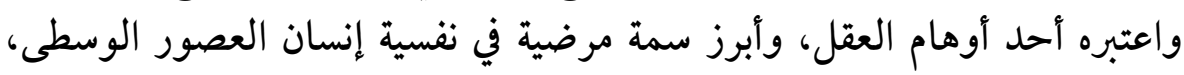

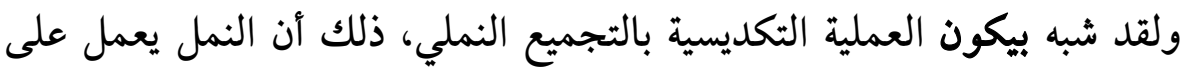

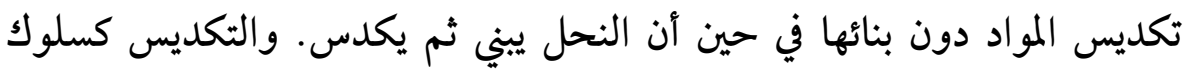


مرضي لا يحل المشكل بقدر ما يزيد في عمق التخلف، وتدهور قيمة الإنسان مهما كانت منزلته الاجتماعية.

5.1 الذريّة : هي نزوع العقل إلى التجزئة والذرذرة الفكرية، وتصبح المشكلات

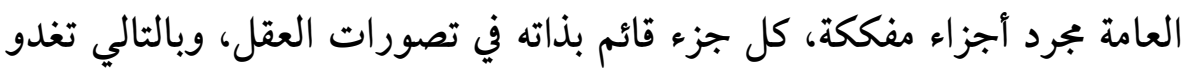

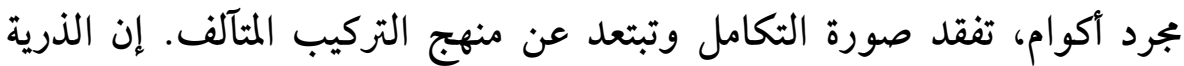

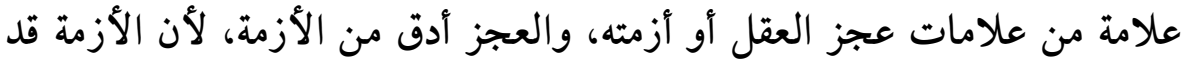

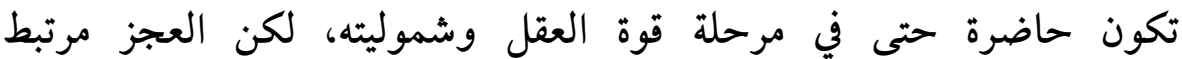
بالانخطاط.

ويذكر مالك بن نبي أن المستشرق الإنجليزي" ماملتون جب" أستاذ بأكسفورد، اتهم العقل الإسلامي بالذرية في كتابه ( LES TENDANCES والومالك لا يوافق جب في جوهرية الذرية في العقل الإسلامي، لأن الذرية حالة من حالات كل عقلي، تتجلى في مرحلة البداوة والبدائية التي تصيب الكائن الحضاري وفي لإن مبدأ الحين الحتمية التاريخية.

ولم تستطع النهضة تعديل العقل أو إصلاحه، بل العكس تماما وقع العقل

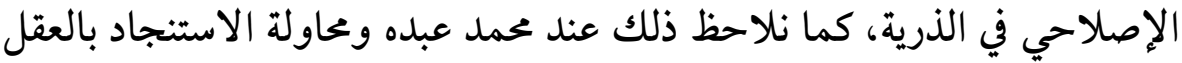
الكلامي لفهم قضايا عصرنا. والذرية رغم كونها بجرد عرض إلا إلا أن الفكر

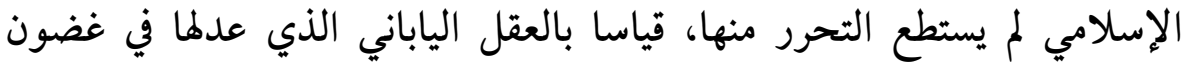

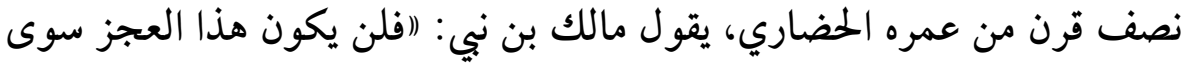

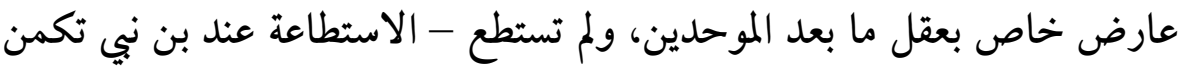

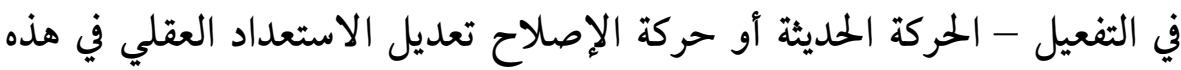
الناحية تعديلا جوهريا)، النيل

6.1 الاغتراب و الانبهار بالغرب: تعمل النظريات الغربية في مجال الفكر التنموي ذات العلاقة بالظاهرة الاستعمارية على تكريس الاغتراب و الانبهار بمنتجاته و

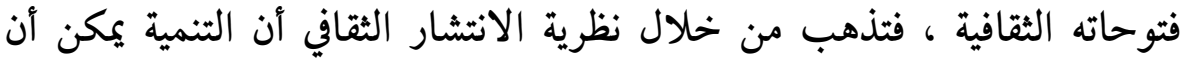


تحقيقها من خلال العناصر المادية و الثقافية السائدة في الدول المتقدمة إلى الدول

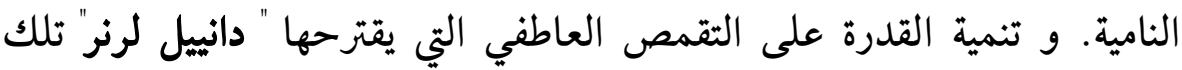

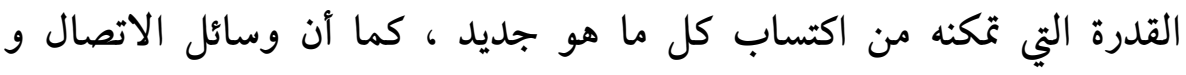

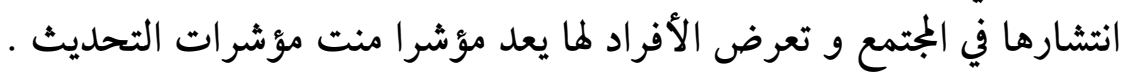

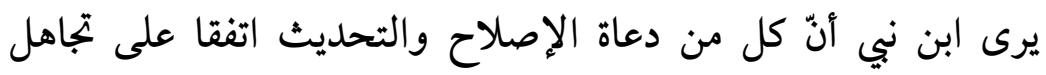

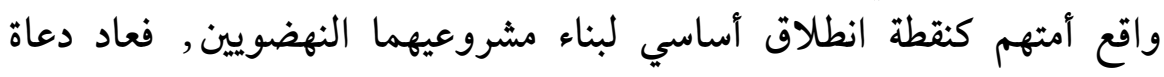

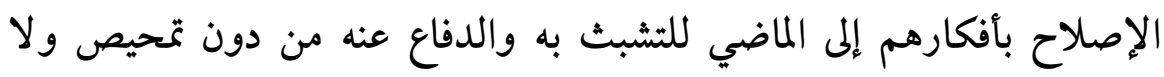

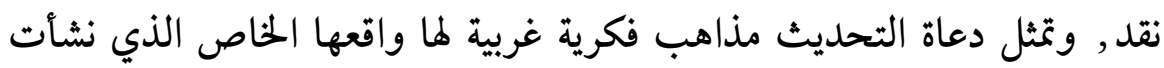

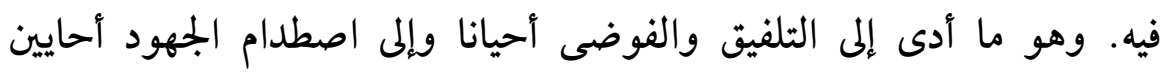
أخرى مما عرقل السير في طريق النهوض.

2. مظاهر التخلف: و قد حدّد مالك بن نيي مظاهر التخلف التي اتسم بها إنسان

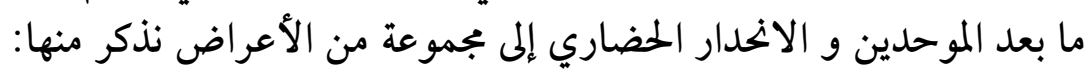

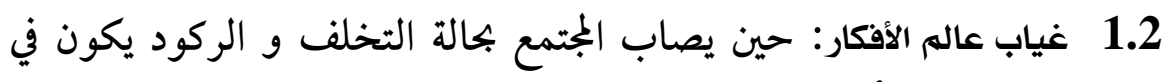

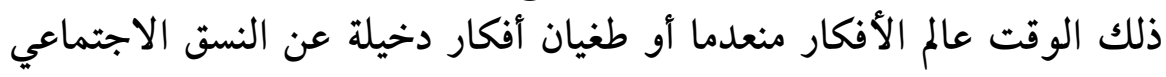

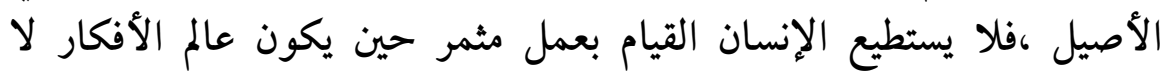

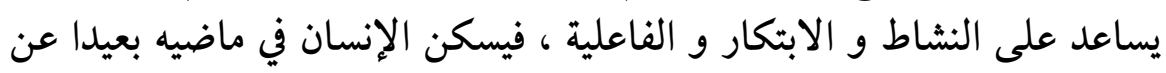

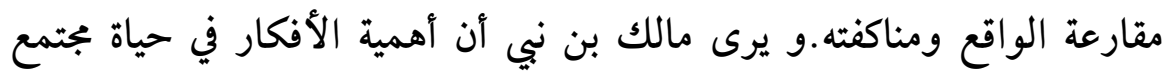

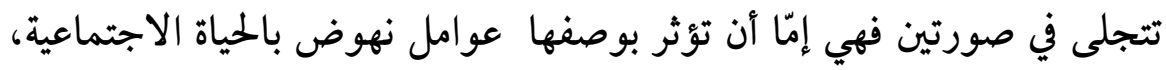

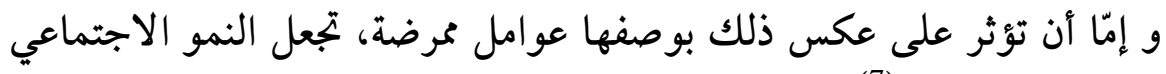
صعبا أو مستحيلا (7) ؤنمان

ذلك أن النشاط الإنساني داخل المجتمع هو انعكاس لعالم الأفكار، و عملية

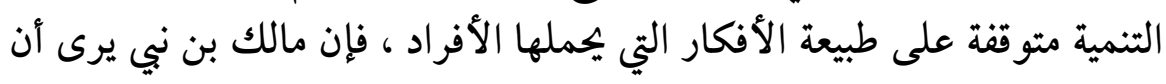

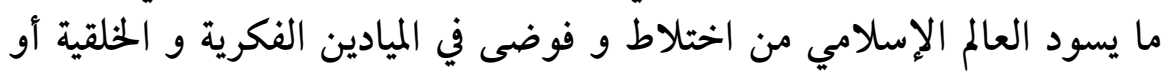

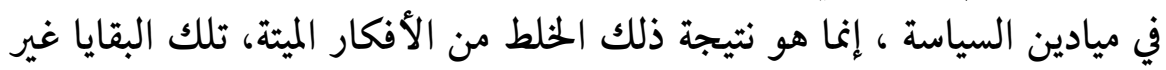


المصفاة، من الأفكار المستعارة التي يتعاظم خطرها كلما انفصلت عن إطارها التاريخي و العقلي في أوروبا (8). 2.2: تززق شبكة العلاقات الاجتماعية : و هي حالة تنتج عن سيادة النزعة

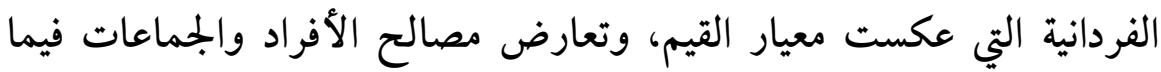
بينها الذي أحدث الاصطدام الداخلي وقضي على العمل التكاملي الجاد وأدى الجى

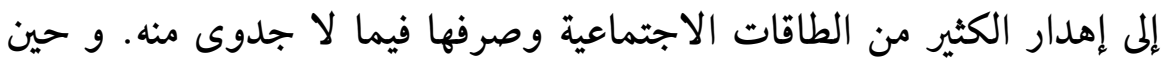
ترتخي شبكة العلاقات الاجتماعية في مرحلة الانحطاط الحضاري، و و تكون بذلك عرضا من أعراض التخلف الذي يسود المجتمعات المتخلفة و تذوب الذاعيه فيه الأفكار البناءة و الفاعلة .

3.2: فوضى الأفكار والتكديس: فالمجتمعات النامية هي التي تحقق الانسجام و

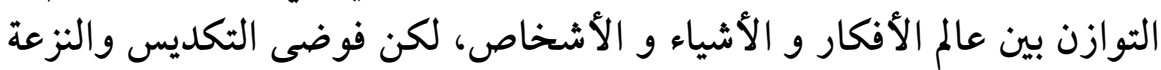

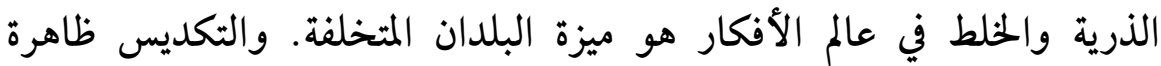

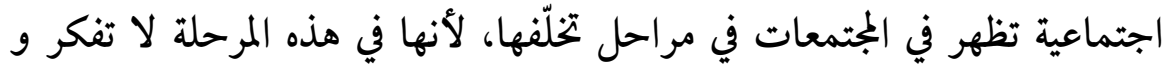

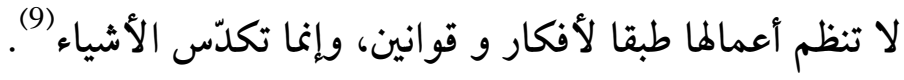

فالمجتمعات التي دخلت في مراحل التخلف الحضاري ، تختل الموازين عندها و

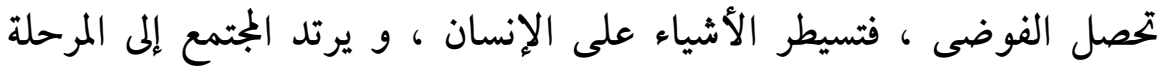

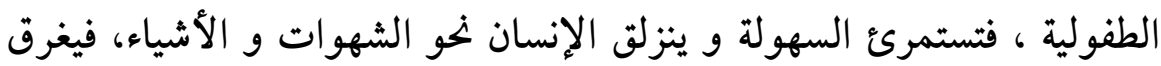

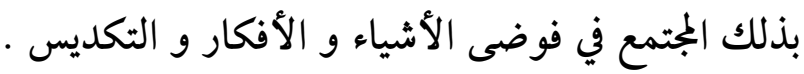
4.2: الشيئية : للشيء حضور قوي وسحر في الذات، لتعلقه باللذات

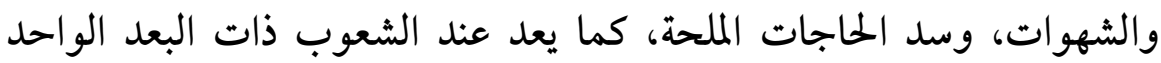
معيار القوة والحضارة، والسلوك الاجتماعي عندما يطغى عليه الشيء ترى جميع

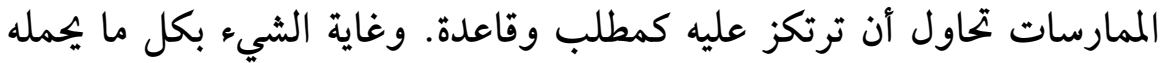

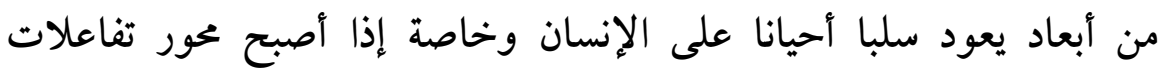


الذات، والإنسان الجاهلي كان غارقاً في عالم الأشياء فتحول سلوكه إلى مادي

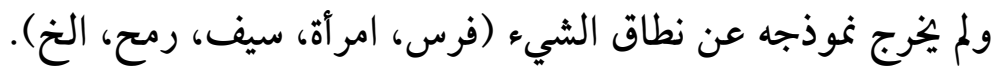
وعندما يفقد الإنسان السيطرة على الشيء يتحول فكره وسلوكه إلى

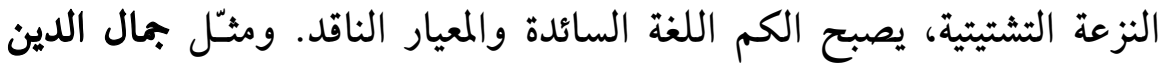

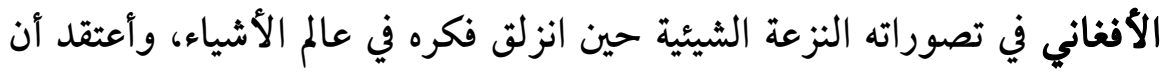
حل المثكلات الحضارية يكمن في الشيء.

وإبن نبي يحاول من خلال إبراز الشيئية كنزعة مرضية أن يلفت الانتباه

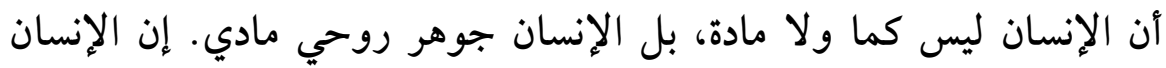

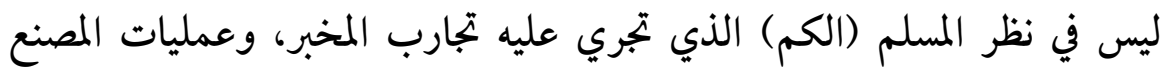
وحاجات الجيش، فالإنسان ليس (الكم) بل (الصفة).

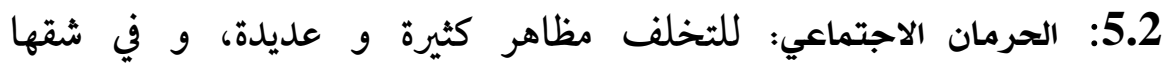

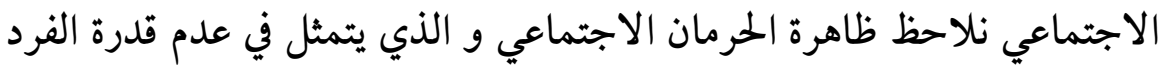

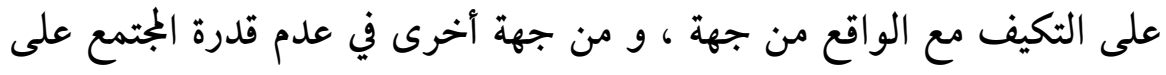

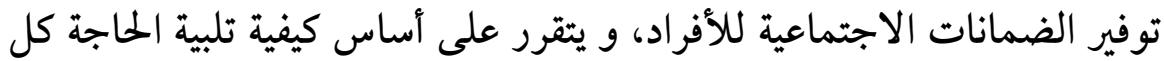

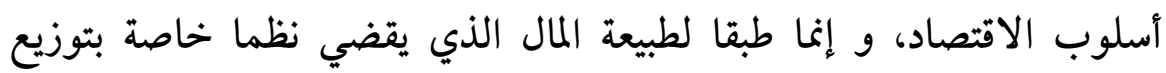

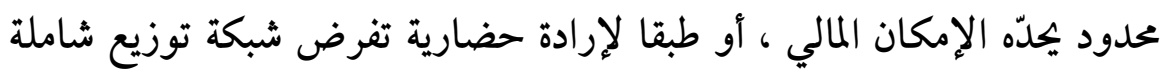

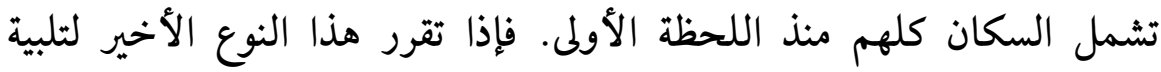

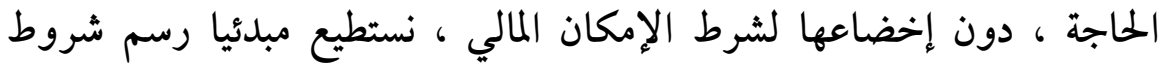
الديناميكا الاقتصادية في صورة مسلمتين : أ/ لقمة العيش حق لكل فم · ب/ العمل واجب على كل ساعد.

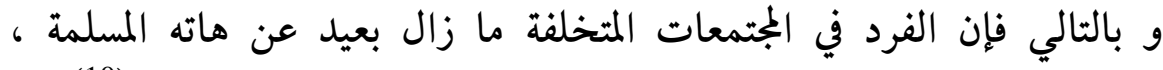
المتأرجحة بين الحق و الواجب في إطاره الاجتماعي ذو البعد الاقتصادي (10). 
6.2 : النزعة السياسوية و فئة الانتقاليين وسلوك الاستبداد: إن احتدام الصراع

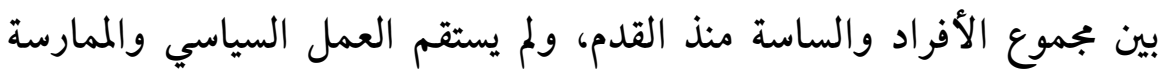

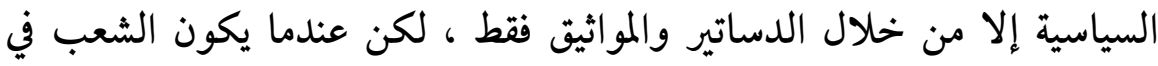
ذروة الحضارة. ولعل أبرز مؤشر المعالم الانهيار يكمن في السياسة، أن مشكلة فئل

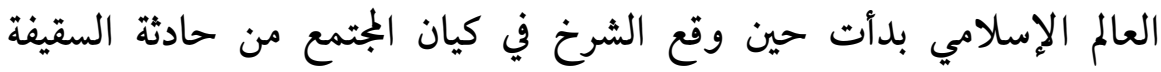

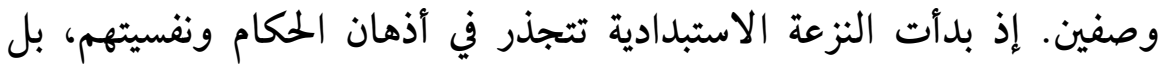

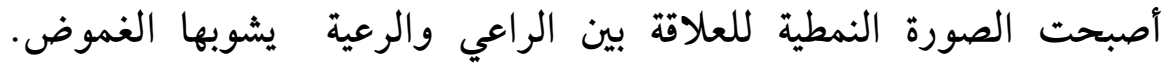

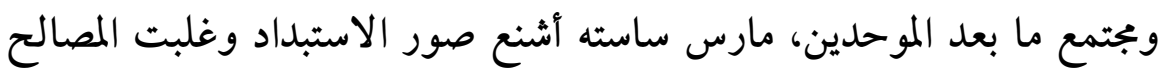

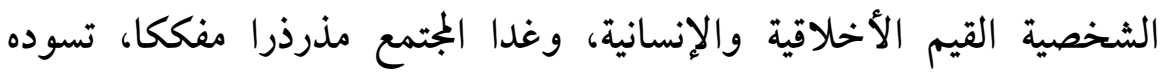

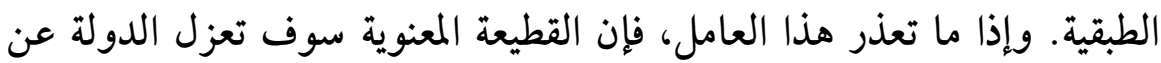
المواطن وتشل الطاقات الاجتماعية، أو تشتتها تشتيتا تكون نتائجه: عدم إنهام

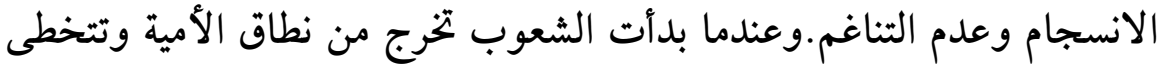

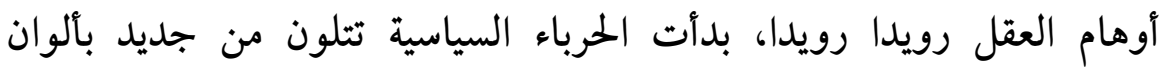
الإغراء والوعود، والشعارات البراقة، خصوصا حين ترفع شعارات خلابة وتصرح بوعود مغرية.

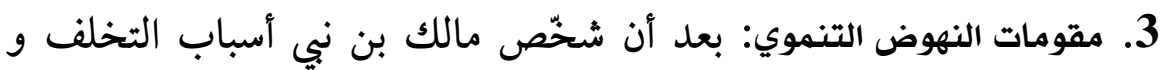
مظاهره التي تمحورت حول طبيعة الإنسان من جهة، عدم التحكم في آليات و

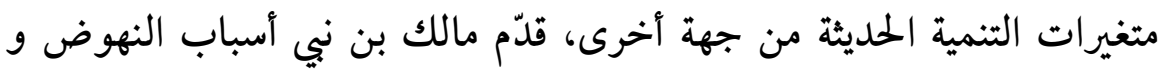

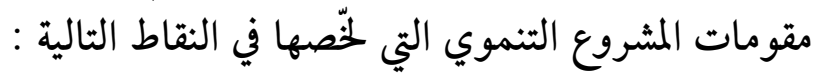

1.3 : الاستثمار الاجتماعي مقابل الاستثمار المالي: و هي خاصية تتميز بها دول

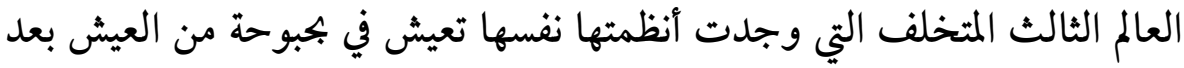
أن شكلت اقتصاد ريعي يعتمد على المال دون الاستثمار في الموارد البشرية التي

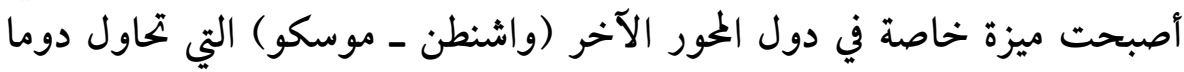

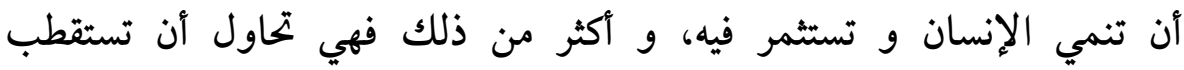


الكفاءات في الدول الأخرى من أجل تطوير ذاتها و اقتصادياتها. لأن المال وحده

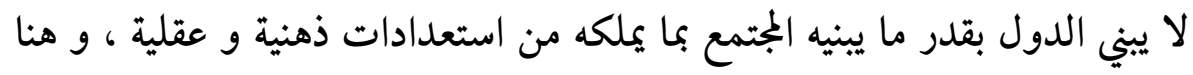

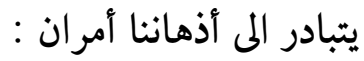

أ/ إن أمريكا لا تستطيع بإمكانها المالي أن تشتري مدينة نيويورك. ب/ بينما تستطيع بإمكانها الاجتماعي بناء أو إعادة بناء مئات مدن مثل نيويورك (11)

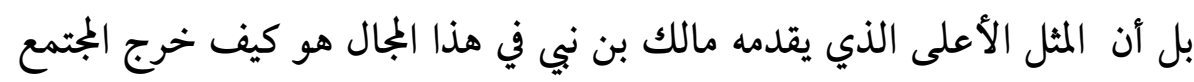

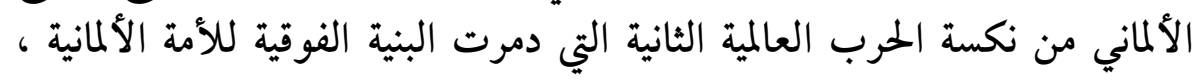

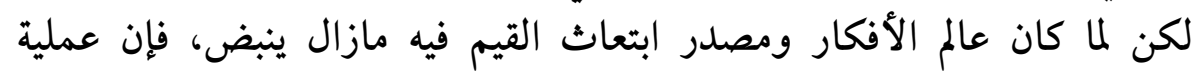

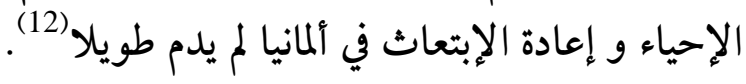

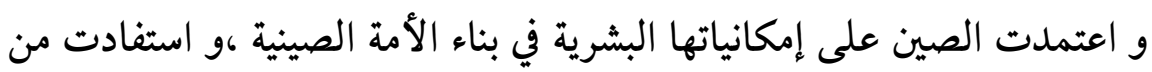

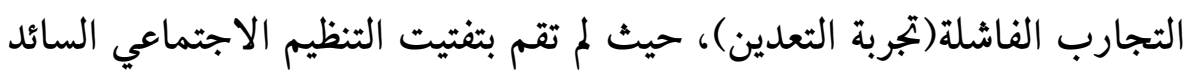

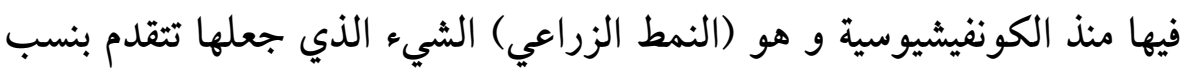

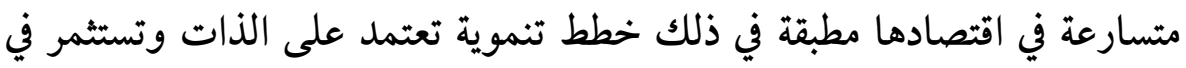

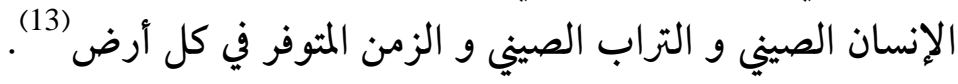

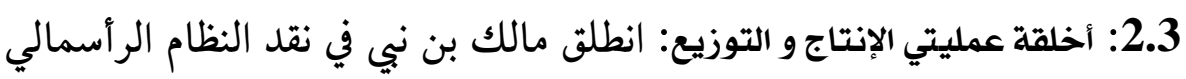

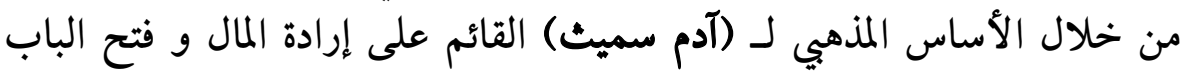

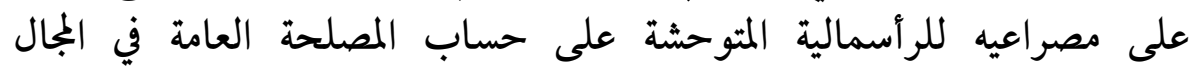

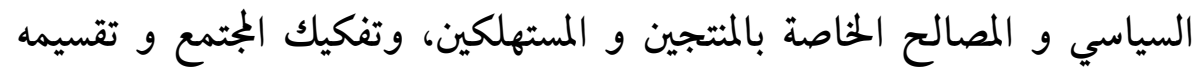
طبقيا باسم الحرية المالية من خلال مبدأ (دعه يعمل دعه يسير).

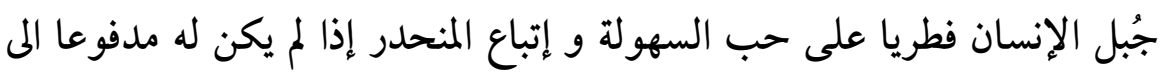

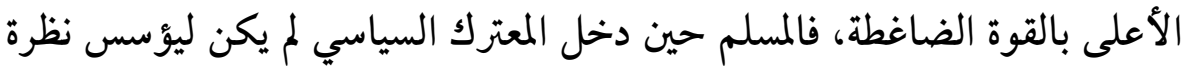

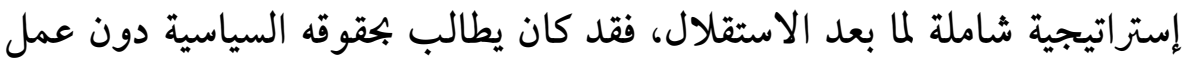


واجباته الأخلاقية حينما كان يركض وراء استقلال لا تؤيده مقومات السيادة

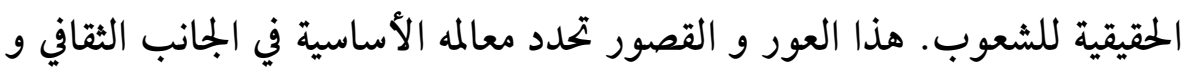
في الأساس الأخلاقي . فالسياسة التي مدئي بالحقوق دون العمل على تمكين المجتمع من القيام بواجباته هو انتحار حقيقي

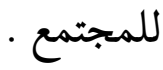

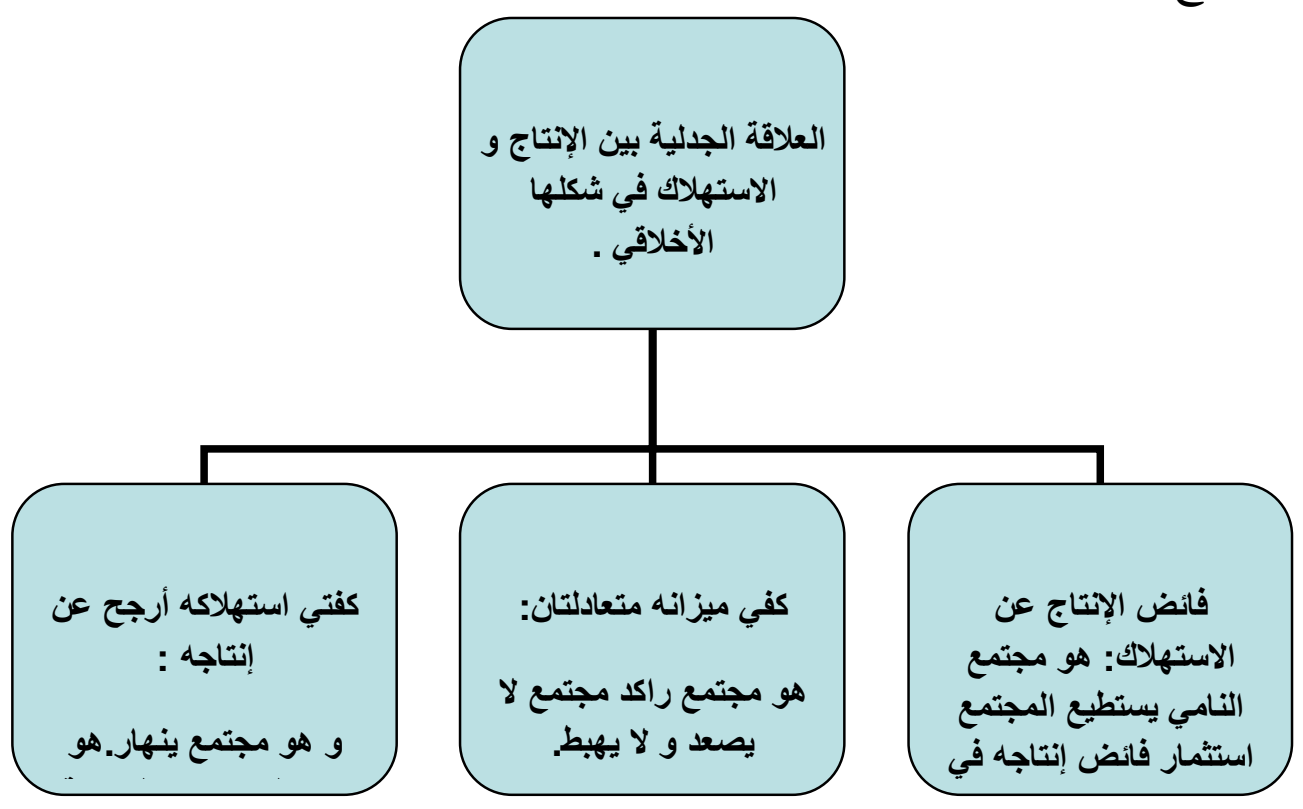

شكل يوضح : طبيعة العلاقة بين الأخلاق و الاقتصاد في مجال الاستهلاك و الإنتاج، المصدر : الباحث.

فيقول مالك بن نبي في هذا الشأن فلو اصطلحنا على المدلول العام

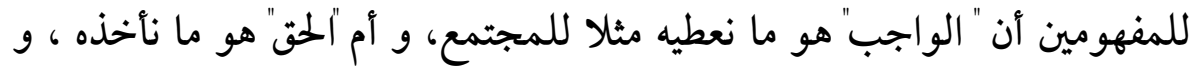

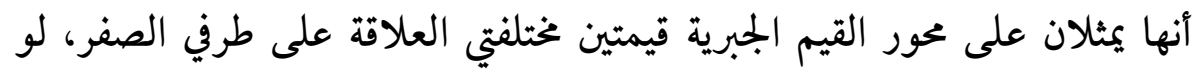

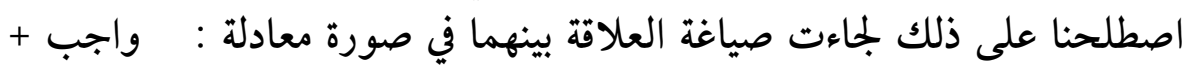
حق = 0.

$$
\text { و كذلك بالنسبة للاستهلاك و الإنتاج: الإنتاج + الاستهلاك = } 0
$$


فهذه التجربة الإنسانية ييب أن تعيد للاقتصاد أخلاقياته و تتلافى الانحرافات

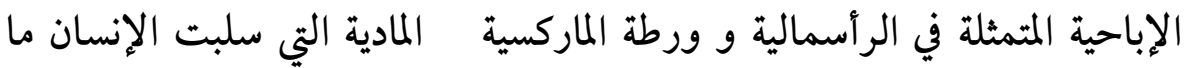
يميزه عن الآلات و الأشياء (14).

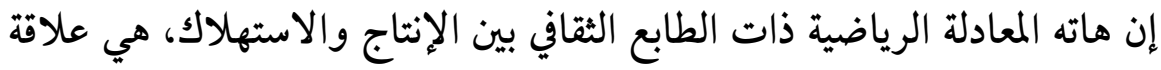

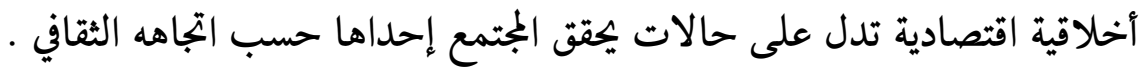
3.3

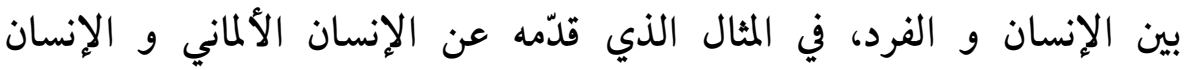

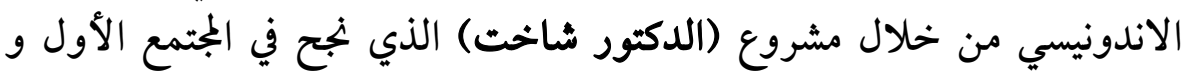

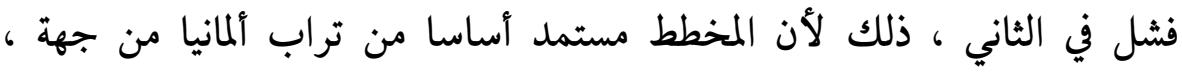

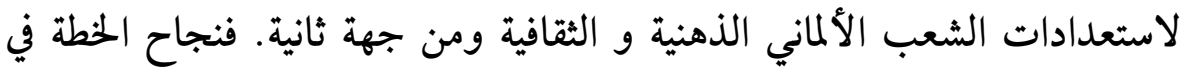

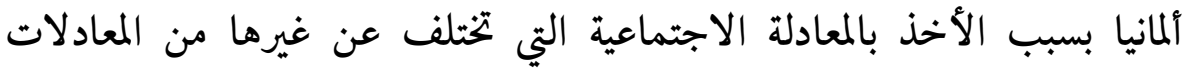

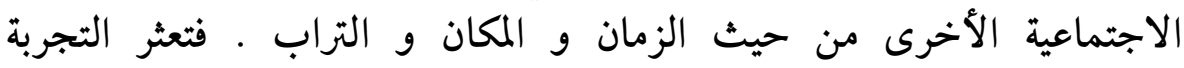

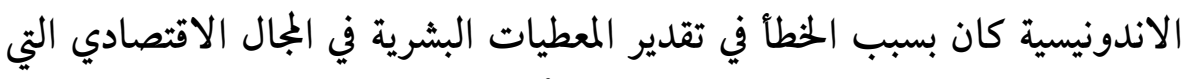

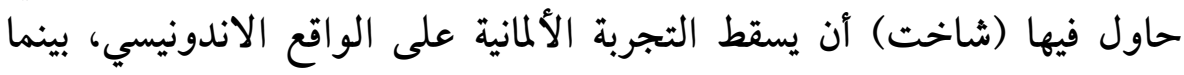

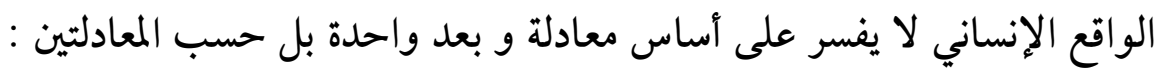

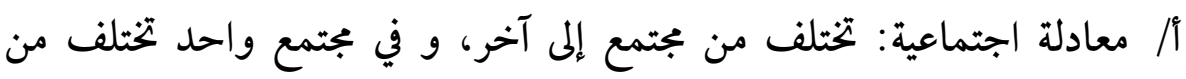
عصر إلى آخر حسب الاختلاف في درجة النمو و التخلف.

ب/ معادلة بيولوجية : تسوي بين الإنسان و أخيه في كل مكان ليستطيع هذا كل

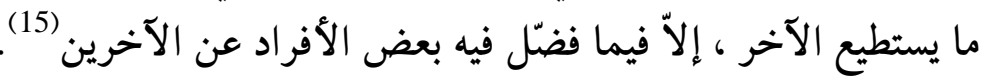

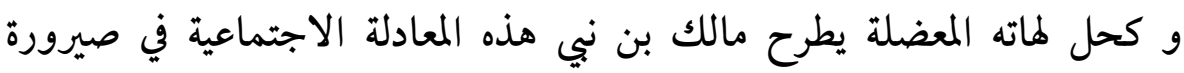

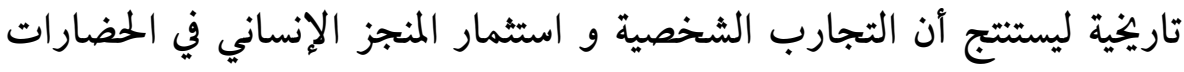

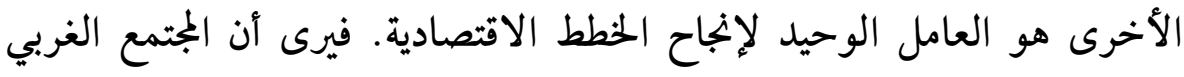

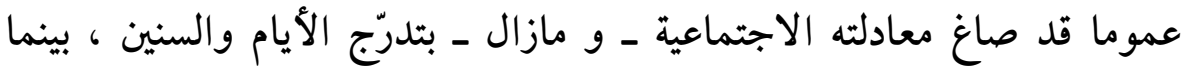

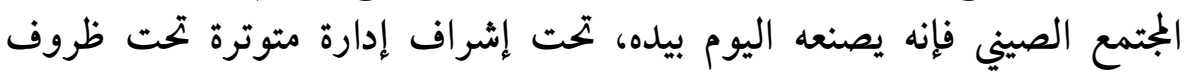


قاسية، كما هو الحال في المجتمع الياباني ـ أما المجتمع الإسلامي فهو في حيرة بين أمرين: ( قاسنية

أ/ إما أن يترك الأيام تصوغ معادلته الاجتماعية أو تعيد صياغتها لتمكينه من التهادي

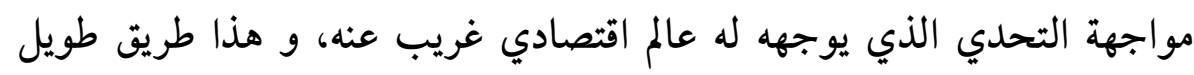
تعبّده تجارب و محن المجتمعات الأخرى.

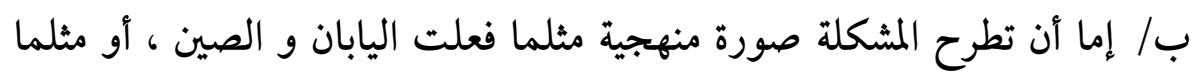

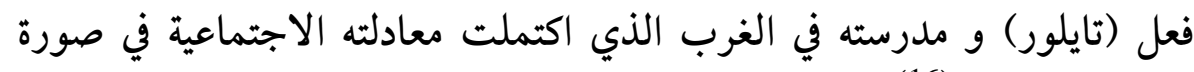
النظرية التايلورية (16).

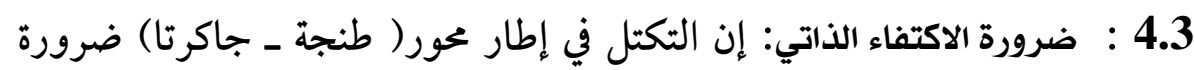

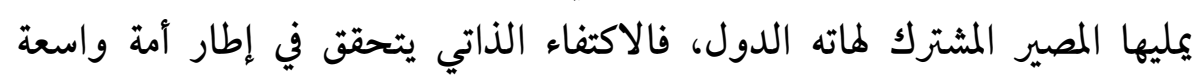

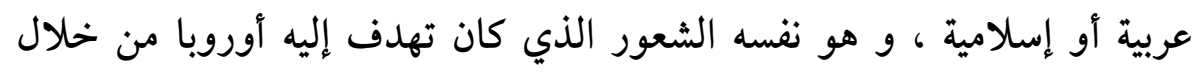

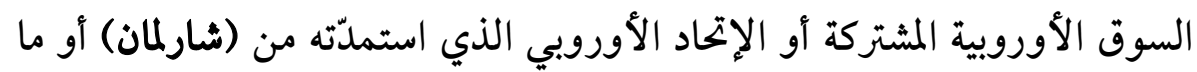

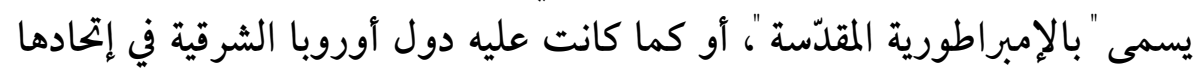

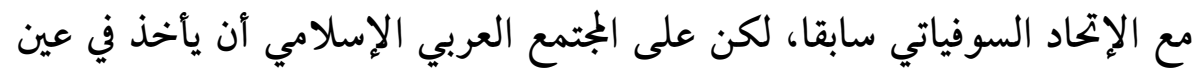

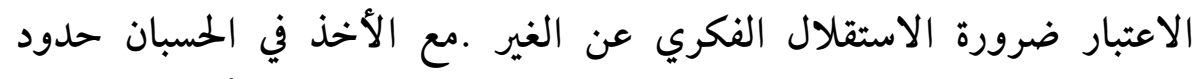

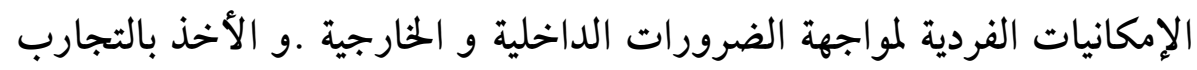

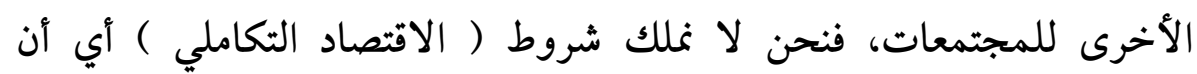

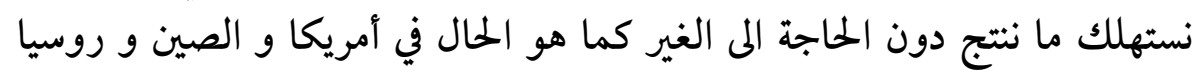

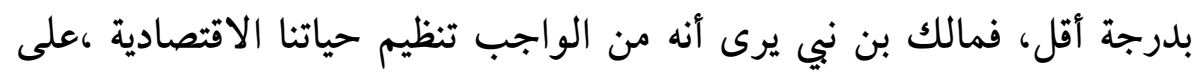

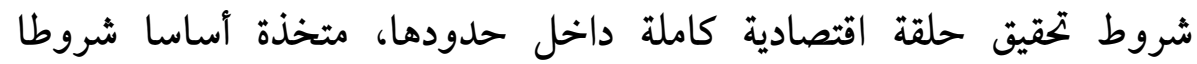

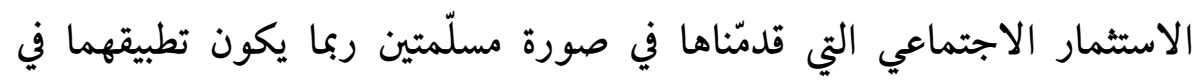

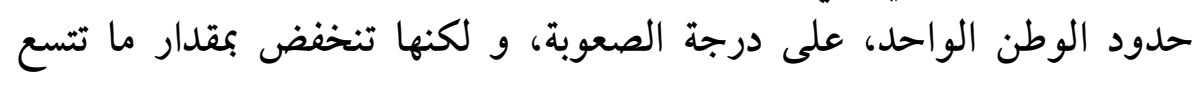

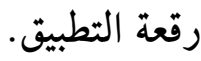


5.3 : بناء شبكة العلاقات الاجتماعية: تعرّف بأنها: بجموع العلاقات الاجتماعية

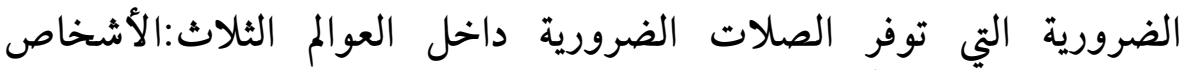
والأفكار و الأشياء (17).

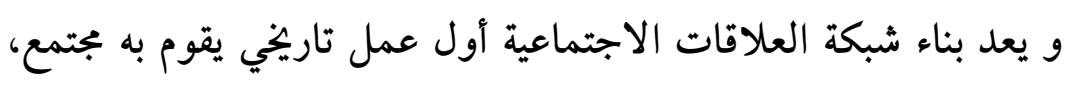

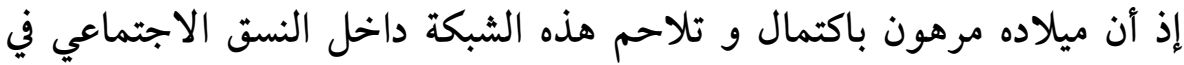

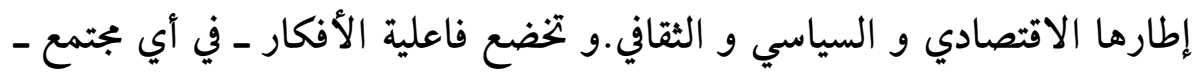

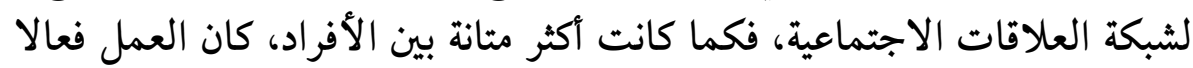
مؤثرا (18).

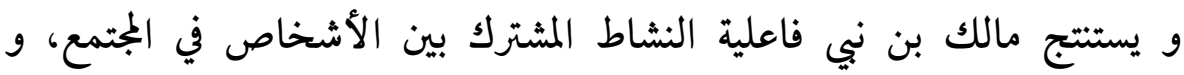

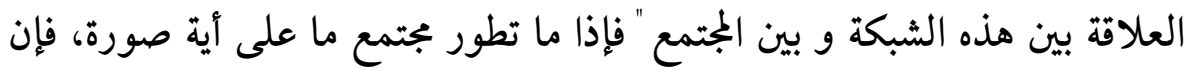

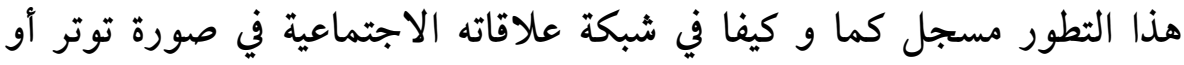
ارتخاء في التوتر، أو في تفكك الشبكة نهائيا عند مرحلة أفول المجتمع (19).

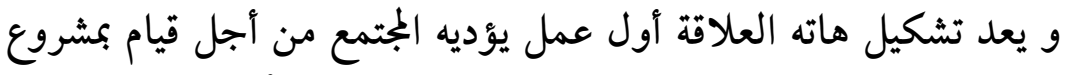

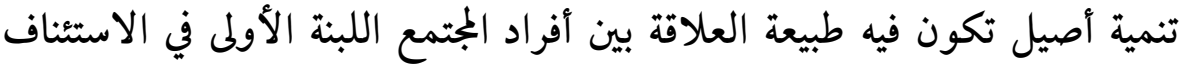

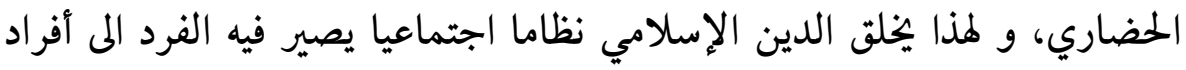

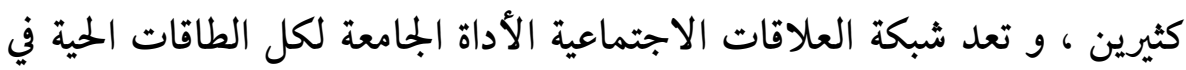

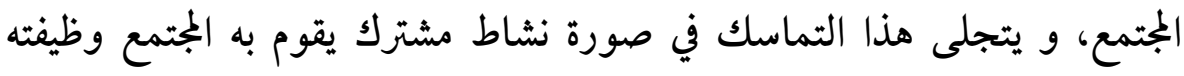

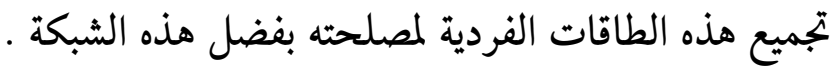

6.3: التنمية السياسية: وهذا يستدعي ضرورة مراجعتنا لتصوراتنا النظرية التئية

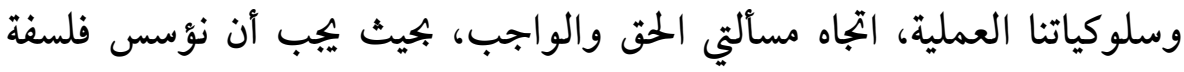

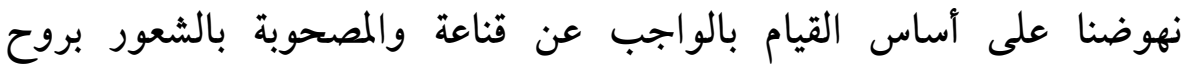

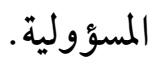

وتحقيق انسجام عمل الفرد مع عمل الدولة من خلال العمل على رأب المقاب

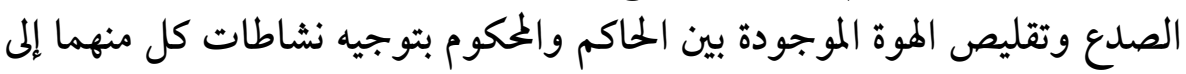


اتجاه موحد تتجانس فيه جهودهما وتتكامل، فالفعل السياسي لن يحقق نجاحه إلآ

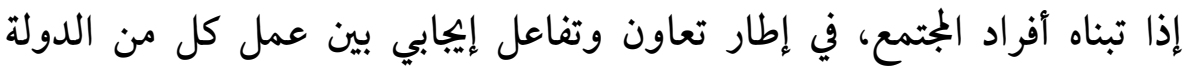

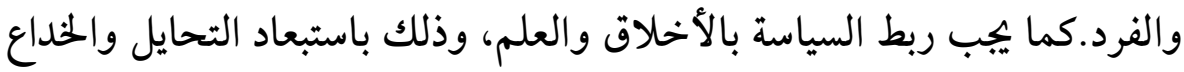

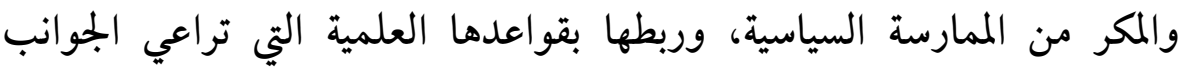

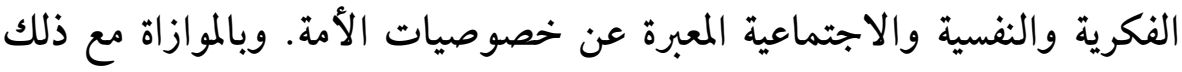
يجب العمل على توفير الوقاية والحماية للمنجزات المققة.

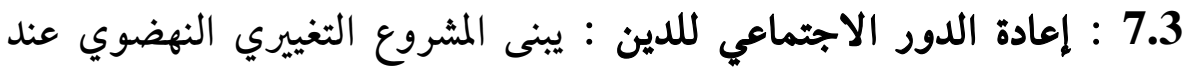

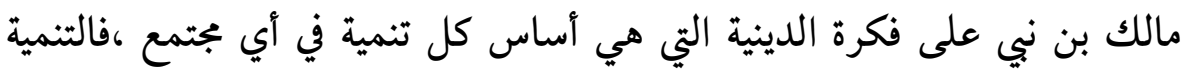

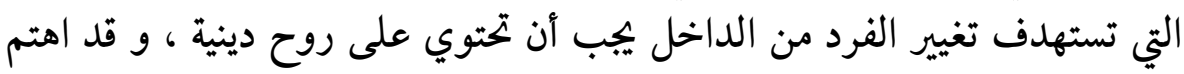

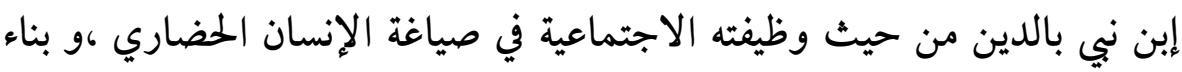
شبكة العلاقات الاجتماعية ، وفي تكوين اللحمة بين عالم الأشخاص و و الأفكار و

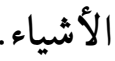

و من هنا نجد أن الوظيفة الاجتماعية لدين تحقق في شكل تركيب يهدف

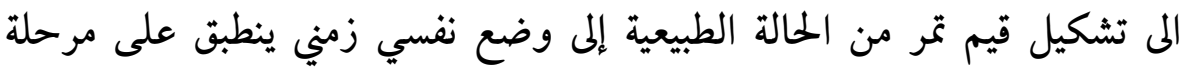

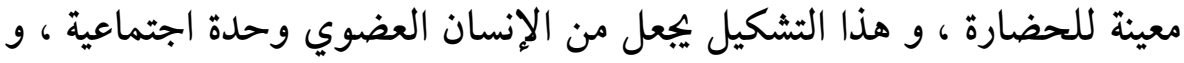

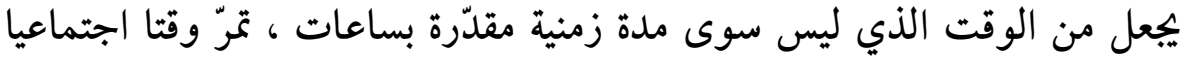

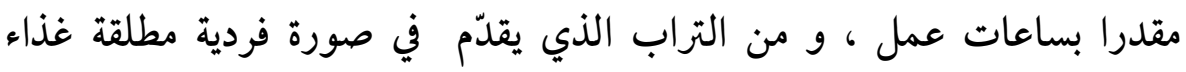

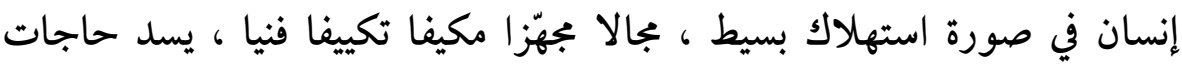

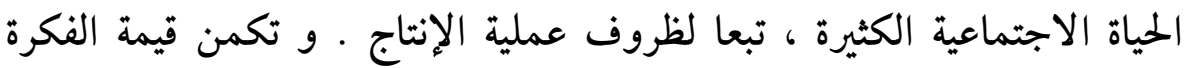

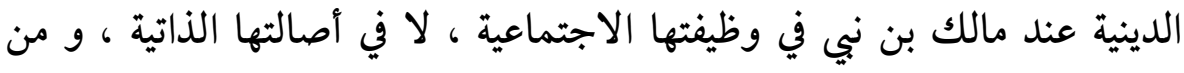

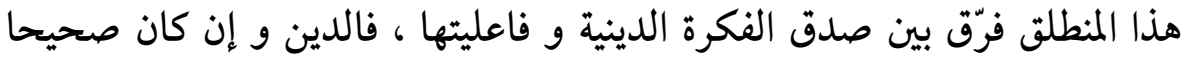

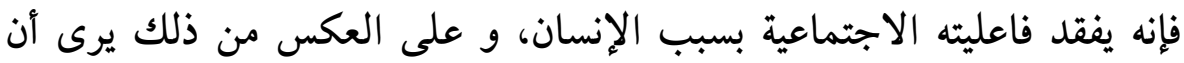

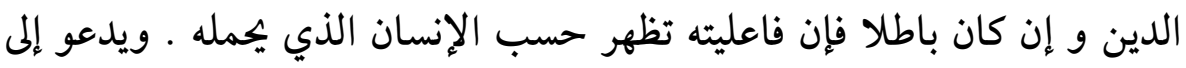

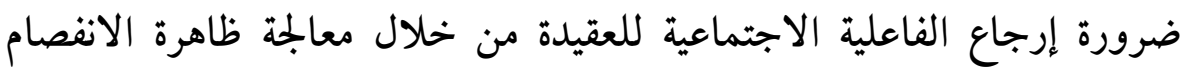




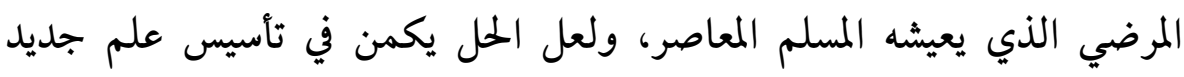

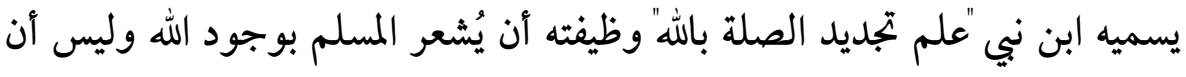
يُبْرهن له على وجوده.

8.3 :بناء الإنسان الجديد غير القابل للاستعمار: وتكمن وظيفة هذا الإنسان الجديد

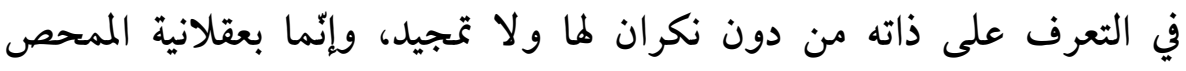

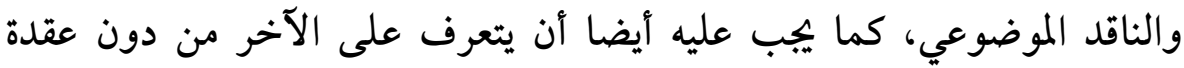

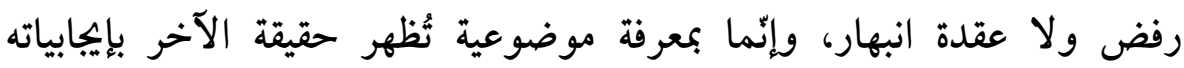

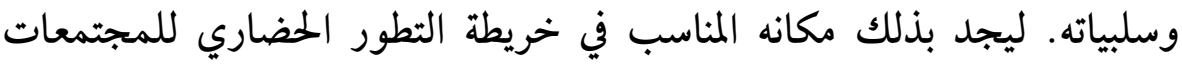

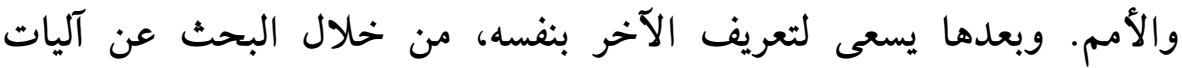

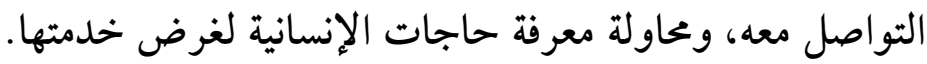

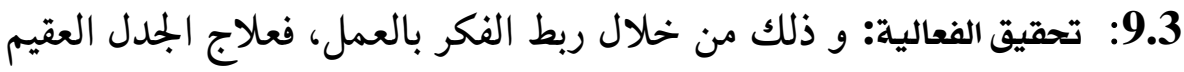

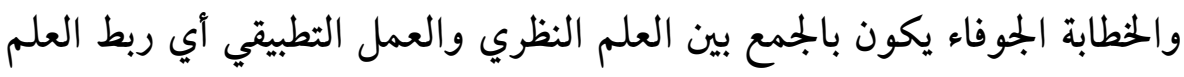
بأهداف عملية معبرة عن مثطلبات الواقع.

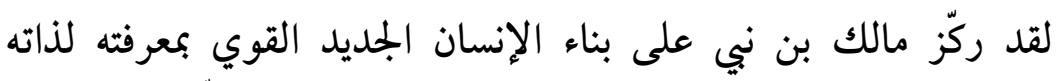

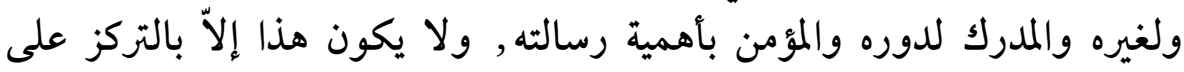

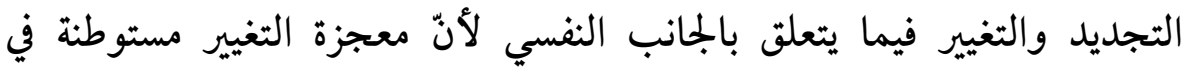

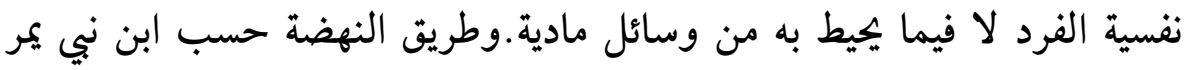

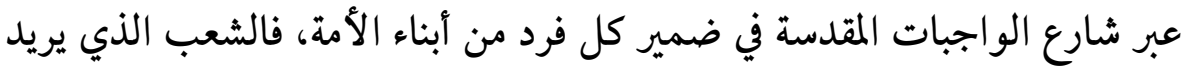

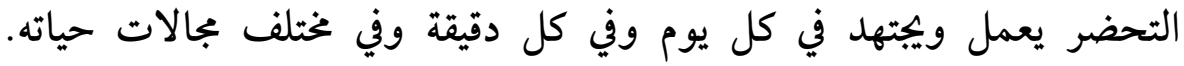

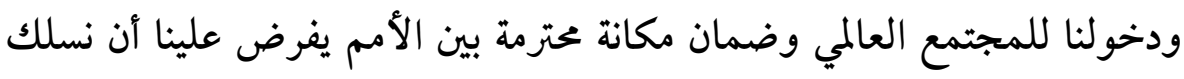

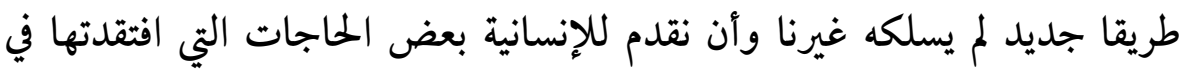

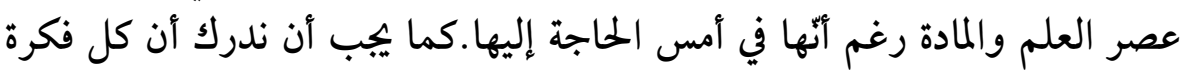

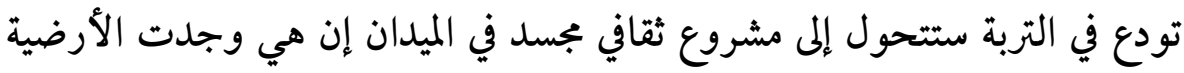
الملائمة واللحظة التاريخية المناسبة. 
4. - ركائز التنمية عند مالك بن نبي:

يؤسس مالك بن نبي لفكرة التنمية من مدخل متكامل يأخذ بالنظرة

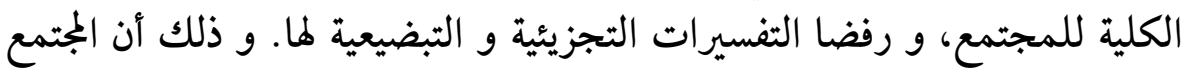

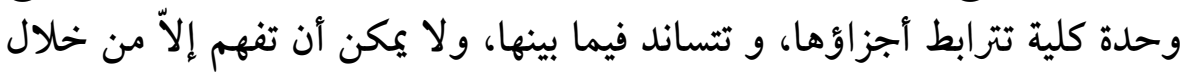

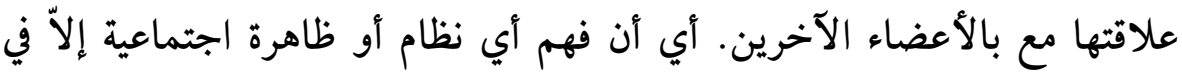

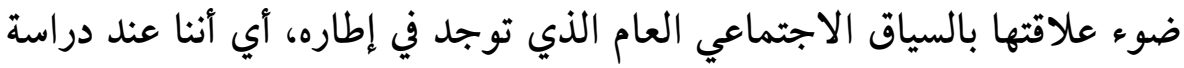
ظاهرة التخلف لا بد من مراعاة كافة مكونات البناء الاجتماعي مثل البناء الديمغرافي ، والنسق الإيكولوجي، والنسق الاقتصادي، والنسق السياسي، النسق

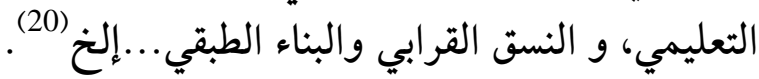
و قد نقد مالك بن نبي المقاربات النظرية التي تأسست في أعقاب الحرب

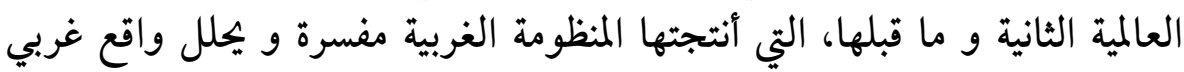

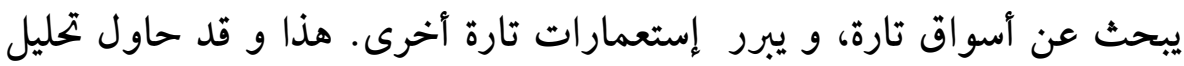

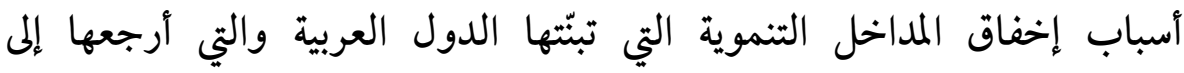

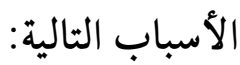

أ/ عدم تشخيص غاية النهضة بصورة واضحة . ب / عدم تشخيص المشكلات الاجتماعية تشخيصا صحيحا. ج/ عدم تحديد الوسائل تحديدا يناسب الغاية المنشودة و الإمكانيات. و يحدد مالك بن نبي شروط التنمية من خلال عوالمه الثلاث، فهي حجر

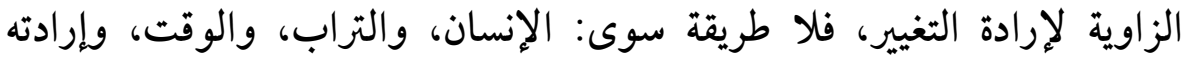

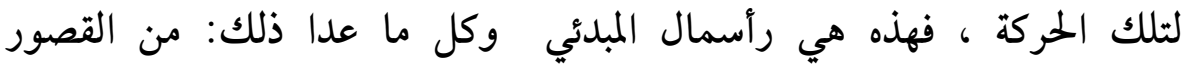

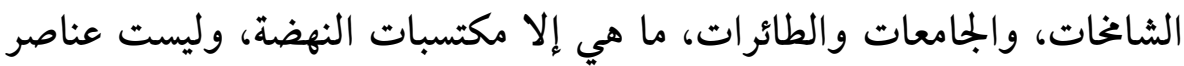

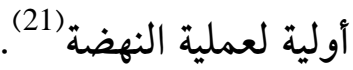


و يضيف قائلا:" وليس من الضروري ولا من الممكن أن تكون لمجتمع فقير

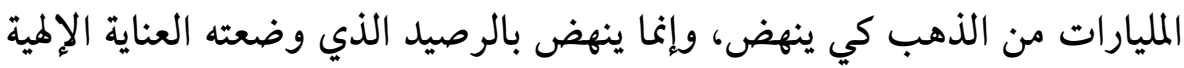

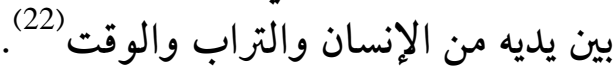

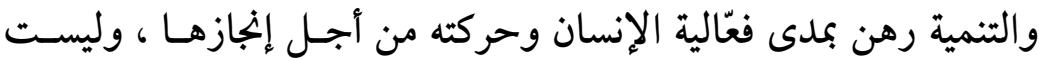

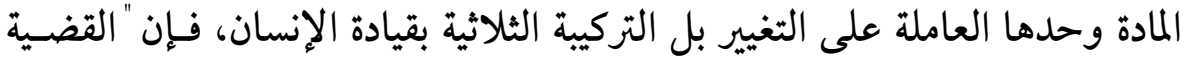

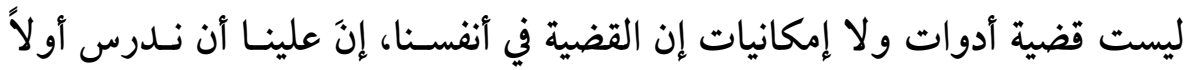

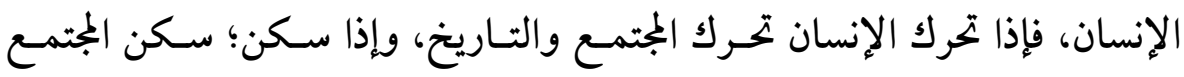

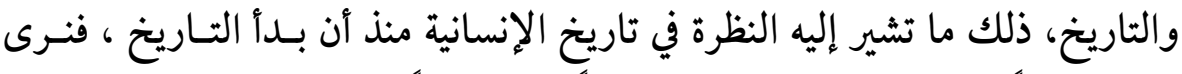

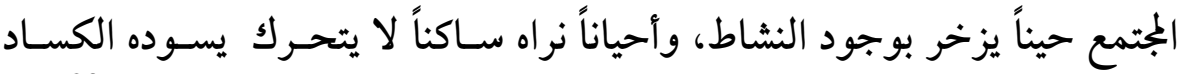

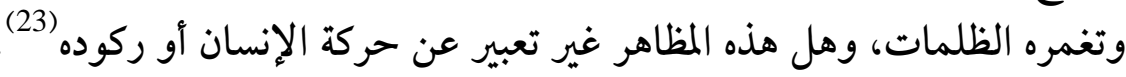

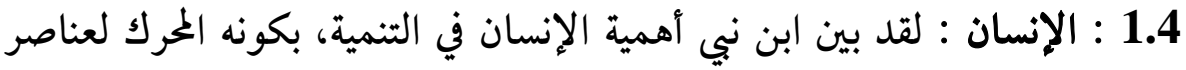

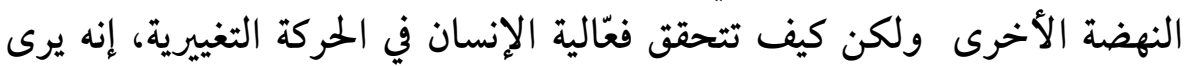

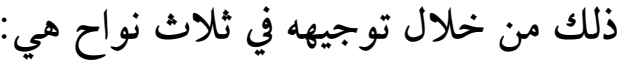

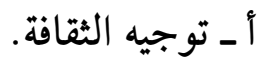

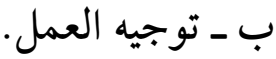

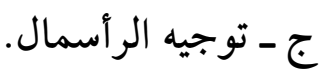

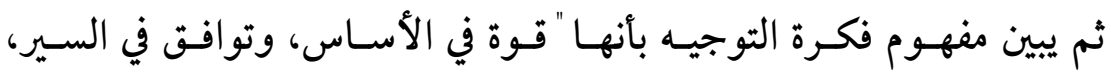

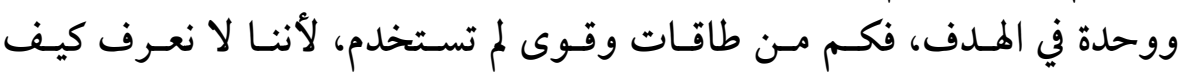

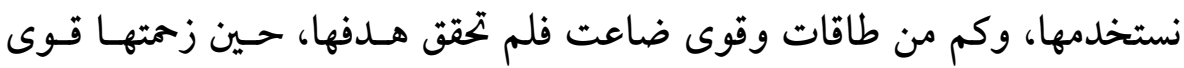

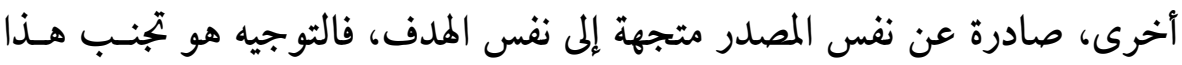

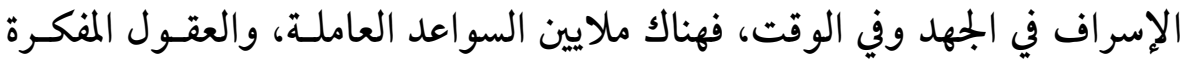

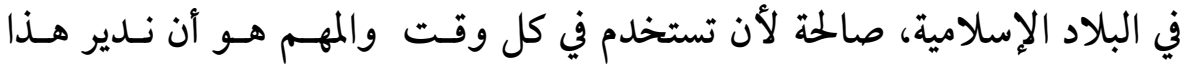

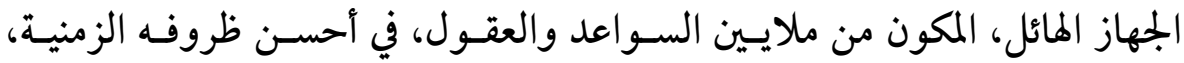


والإنتاجية، المناسبة لكل عضو من أعضائه، وهذا الجهاز حين يتحرك يمدد بجـرى

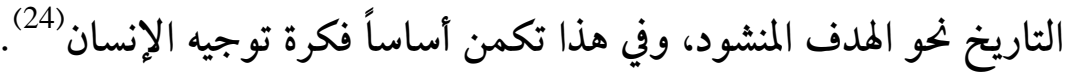

ويذكر ابن ني أن النهضة في العالم الإسلامي بهـا منعطفـات خطـيرة، وأول

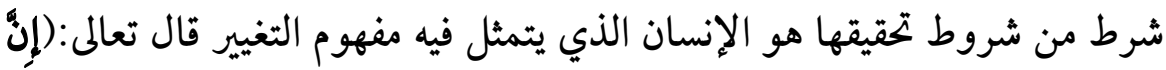

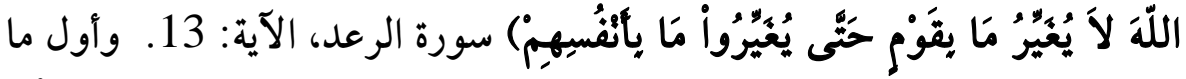

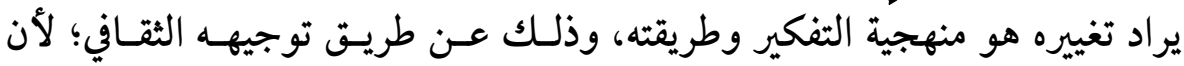

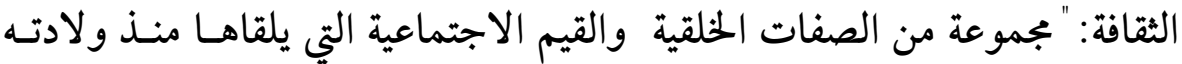

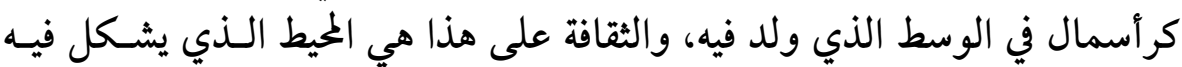
الفرد طباعه وشخصيته (25).

ولكن كيف تعود الثقافة إلى العمل ضمن وظيفتها في التنمية ؟ يرى ابن نبي

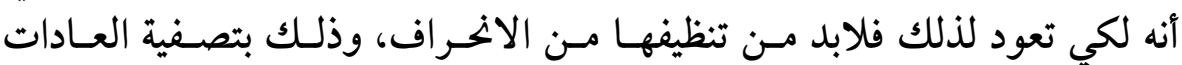

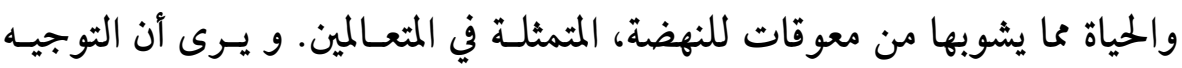

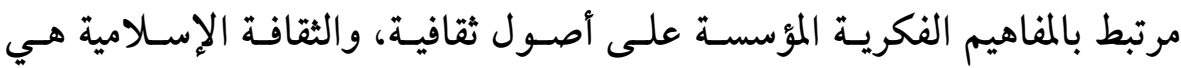

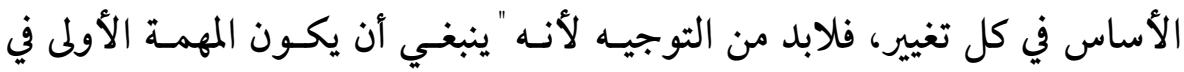

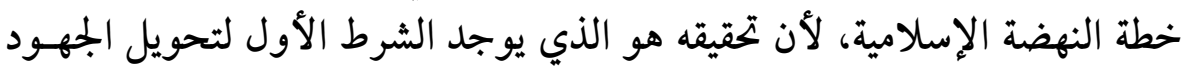
في نطاق هذه النهضة إلى جهود فعّالة (26). 1.1.4: توجيه الثقافة: في حديث مالك بن نبي عن تكوين الإنسان، و تحت عنوان( توجيه الثقافة)، يتعرض لمدلولها فيقول.... و الثقافة من الأشياء الأساسية التي تتطلب بإلحاح تعريفا بل تعريفين : الأول : يحددها في ضوء حالتنا الراهنة .

$$
\text { الثاني: يحددها حسب مصيرها. }
$$

لأن جيلنا هذا حدّ فاصـل بــين عهـدتين: عهـد الكسـاد و الخمـول، و عهـد النشاط و المدنية (27) 
لذا نرى مالك بن بي يبحث عن أسس أية ثقافة من الثقافات، و ينتهي به المطاف إلى أن يحصر عناصر الثقافة في المبادئ التالية :

1.1.4 : التوجيـه الأخلاقي : إن المقصسود مـن التوجيـه الأخلاقسي هـو تـأثير

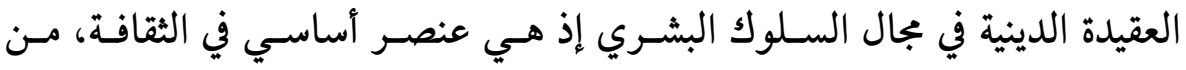

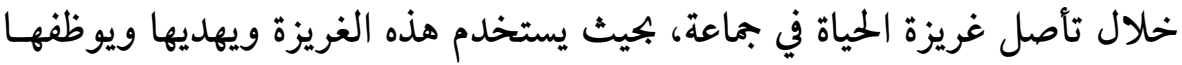

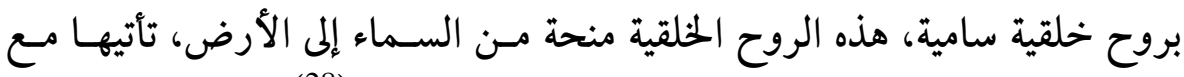

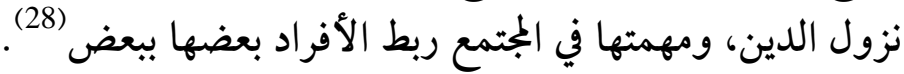

إنه يرى أن الدين هو الأساس الأخلاقي الضروري لعمل التنمية، لأنه منهج

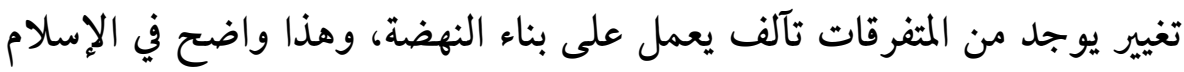

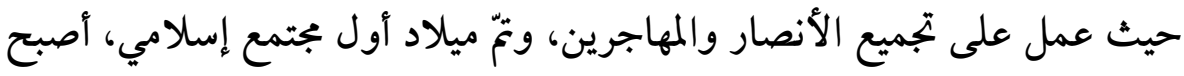

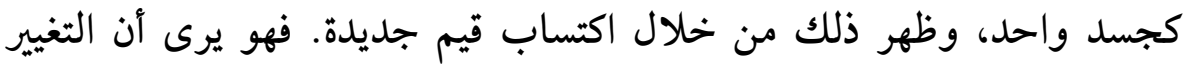

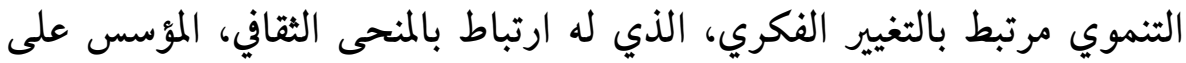

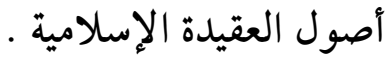

2.1.1.4: التوجيه السلوكي العملي: ويقصد به العقل التطبيقي الذي يجسد الفعاليـة

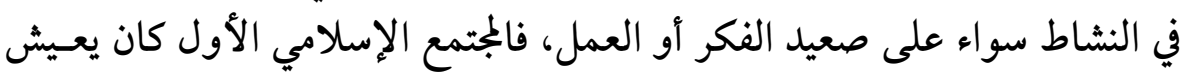

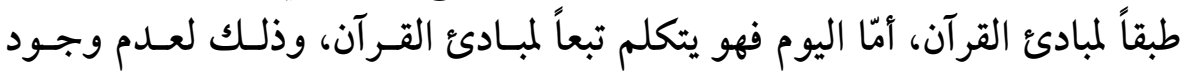
المنطق العملي السلوكي (29).

فإن العقيدة الإسلامية لم يعد لها فعّالية في سلوك الفرد ما كـان لهـا مـن فعّاليـة

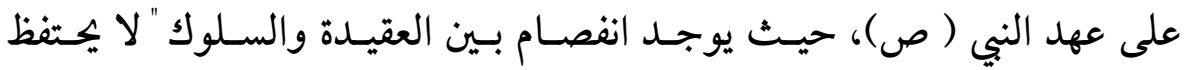
المسلم باستقلاله ابتداء من اللحظة التي يغادر فيها المسجد، فهو يسقط تحت سئ سطوة

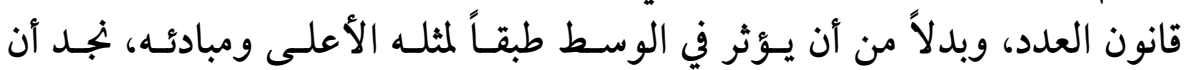
الوسط هو الذي يؤثر عليه (30). 
و يرى مالك بن نبي أن أساس النهضة هو تمثـل العقيـدة الإسـلامية، وذلكك مهـك

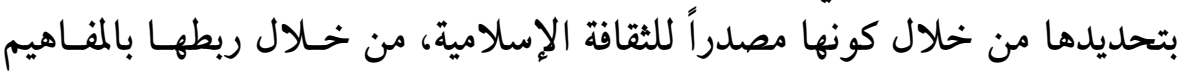

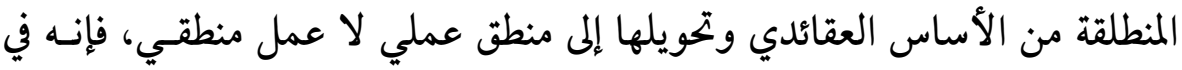

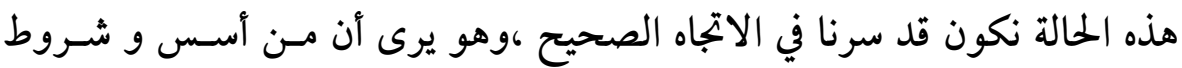

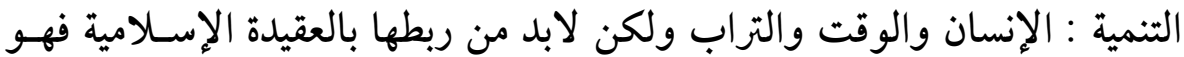

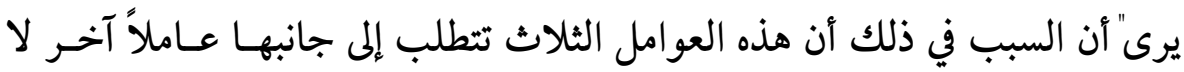
غنى عنه، وهو العامل النفساني، هذا العامل الذي يصطلح على تسميته بالعقيـدة،

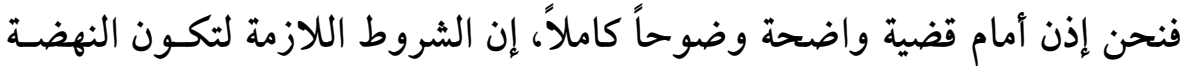

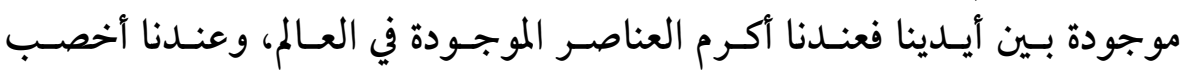

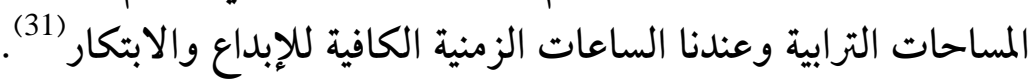

فالمسلم يقتل الوقت والعلـم والمـال، فكيـف ينفـق العلـم ويسـتغل المـال؟ فئا

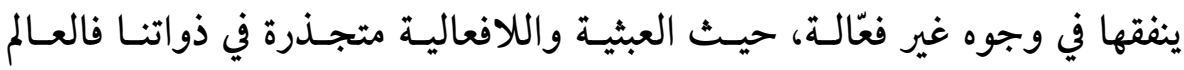

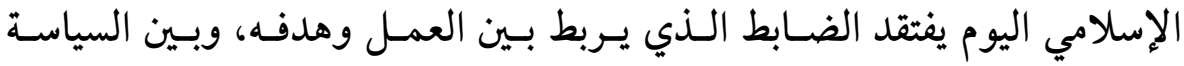

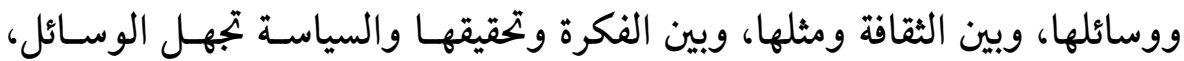

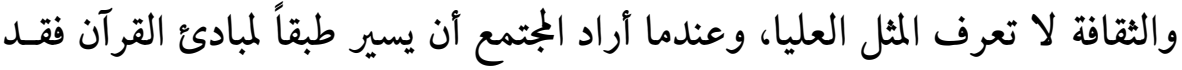

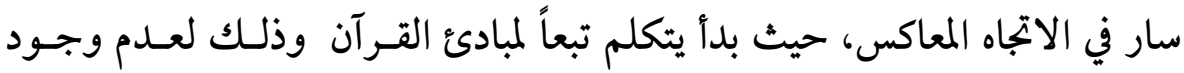

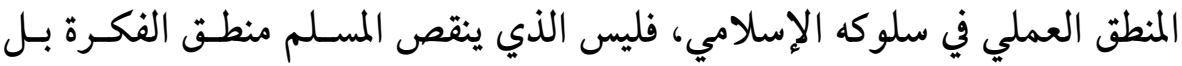

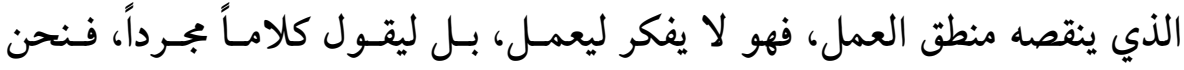
نعيش في أحلام التغيير وينقصنا المنطق العملي (32).

3.1.1.4 : توجيه العمل : يقصد مالك بن نبي بتوجيه العمل: سير الجهود

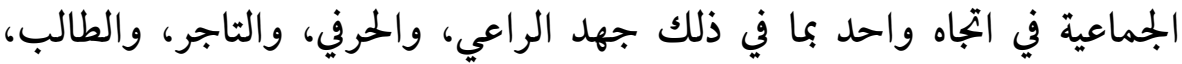
والمثقف والفلاح، لكي يضع كل منهم في كل يوم لبنة جديدة في البناء، فهو تأليف

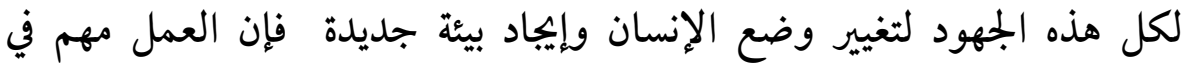
تحقيق مصير الأشياء. 


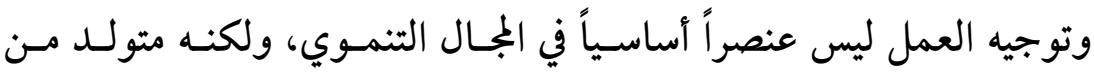

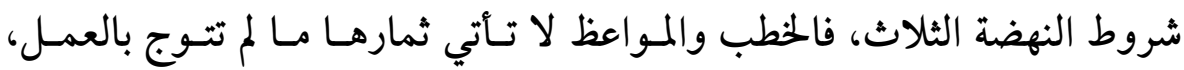

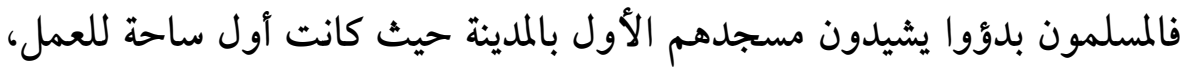

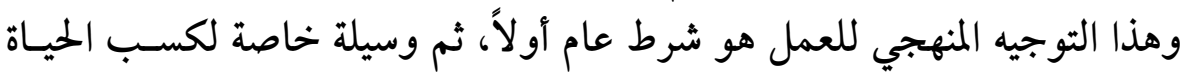

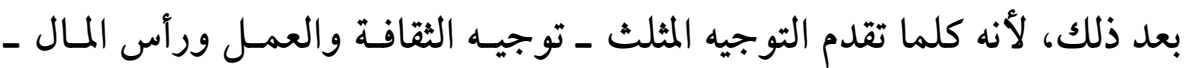
للإنسان المسلم تغير وجه الحياة حتماً فيكتمل ويحتل مستوى أرفع (33).

2.1.4 : توجيه رأس المال: يرى مالك بن نبي أن العـالم الإسـلامي غـني في الجـال

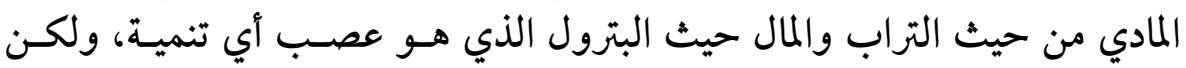

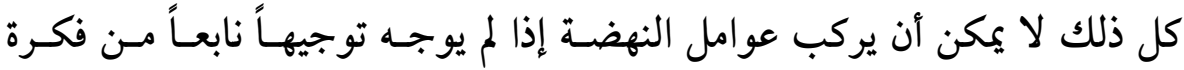

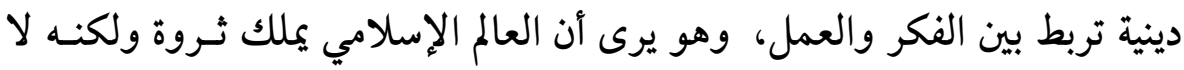

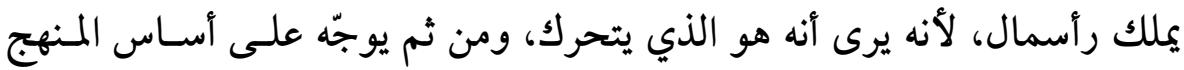

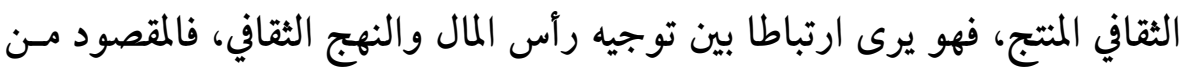

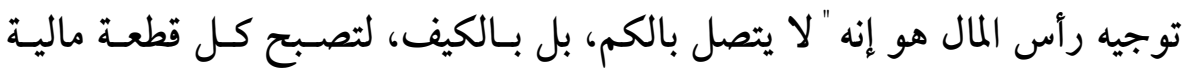

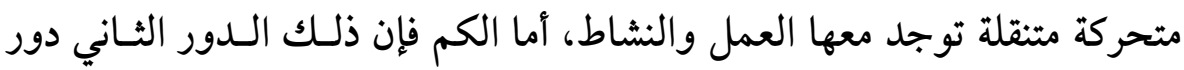

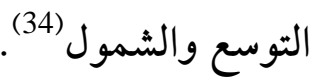

إذن فلابد من تحريك المال وتنشيطه، بتوجيه أموال الأمة البسيطة، وذلك

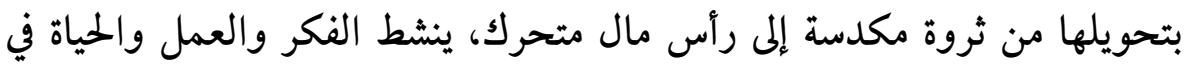
البلاد، فلابد من منهاج يجدد تخطيطاً مناسباً نبني عليه حياتنا الاقتصادية.

2.4 : الـتراب: عنــدما يضـع مالـك بـن نسي هـذا العنصـر لا يقصـد منـه دراسـة

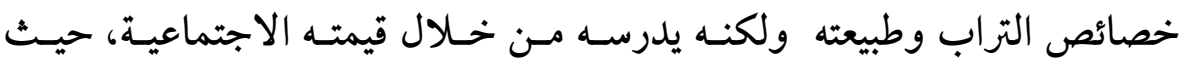

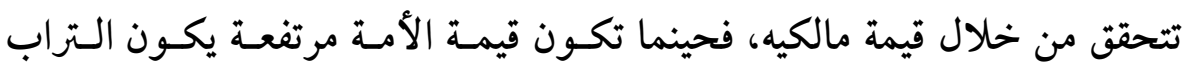

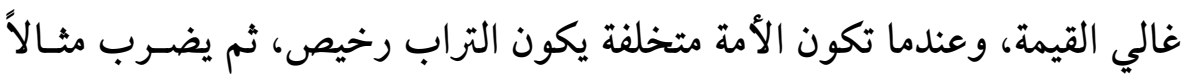

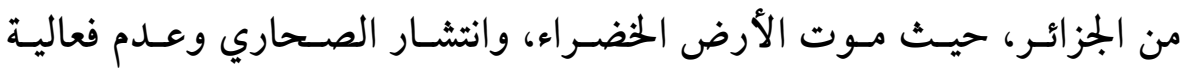

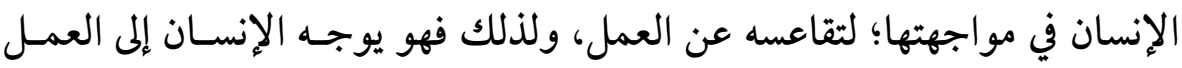




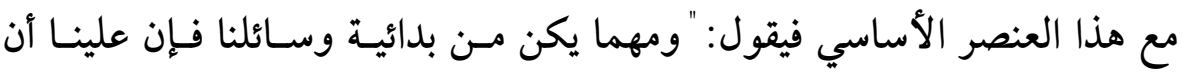

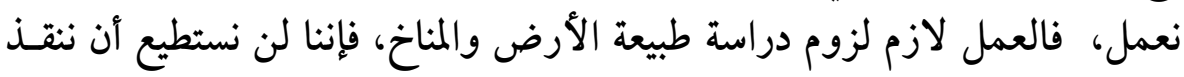

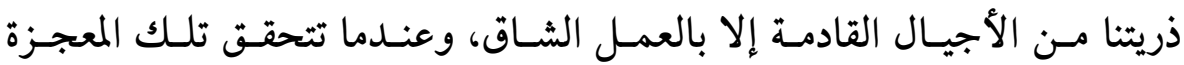

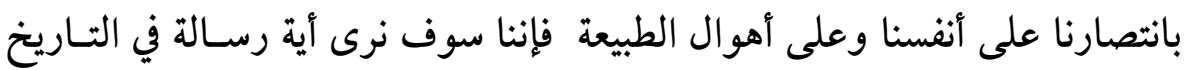

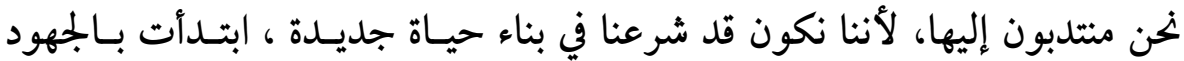
الجماعية بدل الجهود الفردية ، ولسوف تظهر أمامنا بعد ذلك أعمال جلان جليلة خطيرة

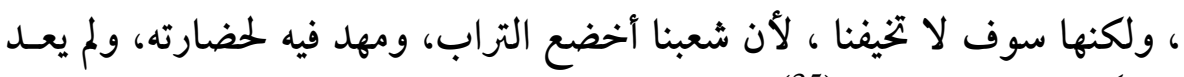

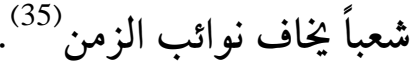

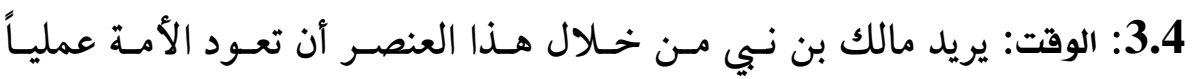

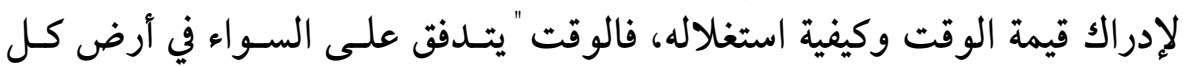

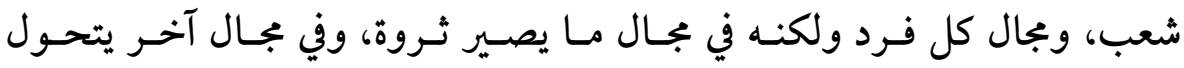

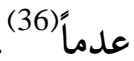

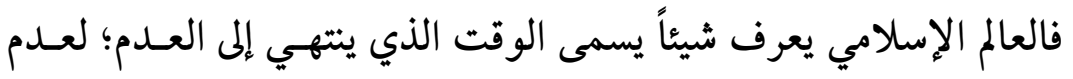

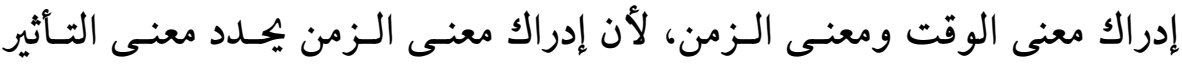

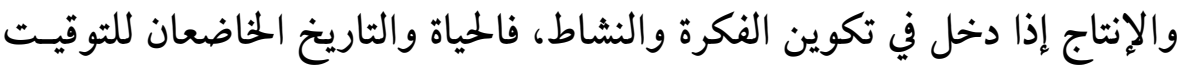

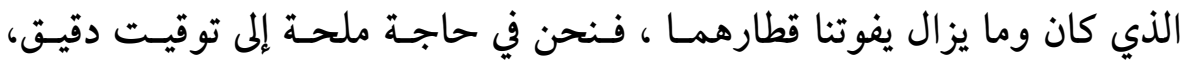
وخطوات واسعة لكي نعوض تأخرنا (37).

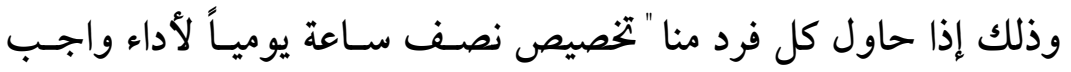

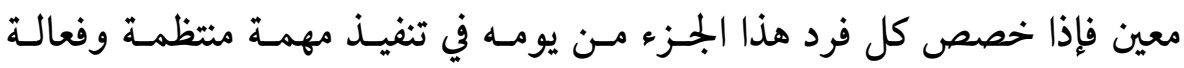

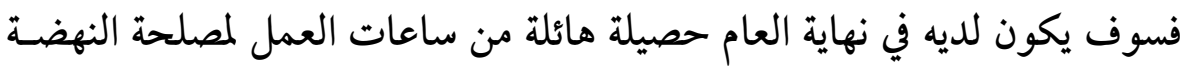

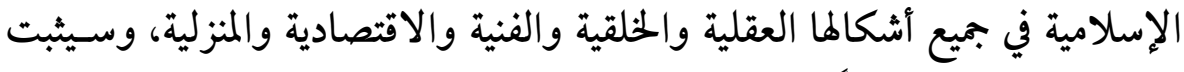

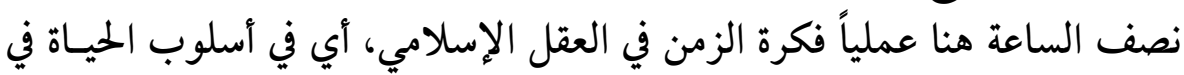

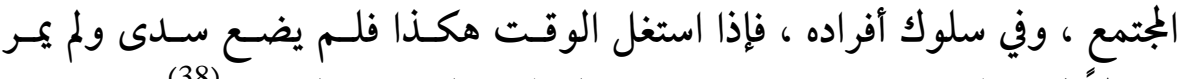

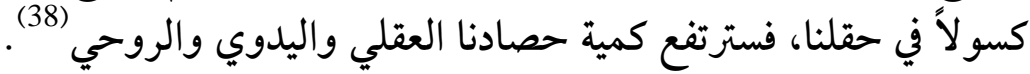


وبذلك تتحقق النهضة و التنمية المطلوبة. وفي نفس الوقت الذي يؤكد فيه مالك

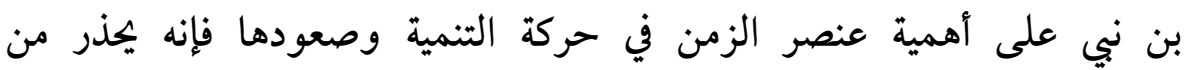

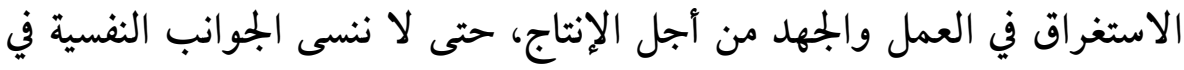

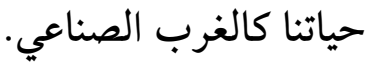

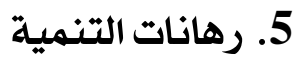

تراهن التنمية في الوطن العربي عموما على شقين أساسيين لا بد من توفيرهما

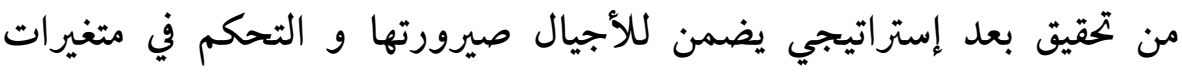

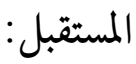

1.5 : التنمية على الصعيد الداخلي: يذهب مالك بن بن بني في تشخيصه للتنمية و

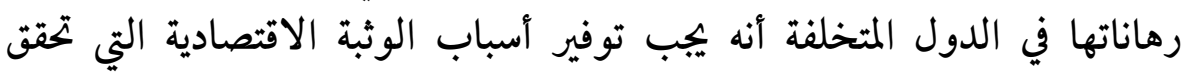

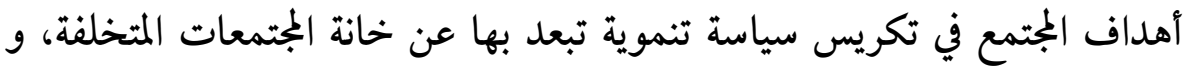
تمثل هذه الرهانات ـ بإيجاز - في :

1.1.5 : فلاحته و هي تزيد أو تنقص بلدرجة وسائله البدائية: إن تحقيق الاكتفاء

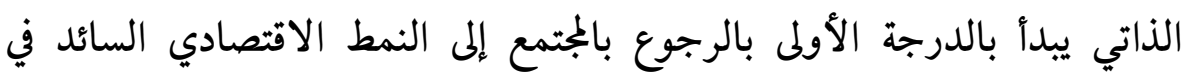

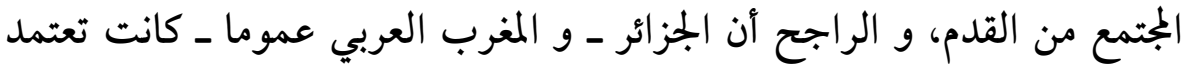

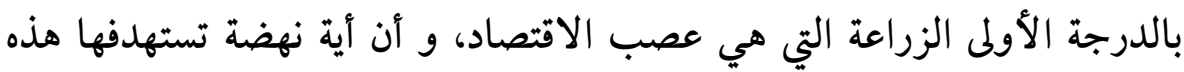

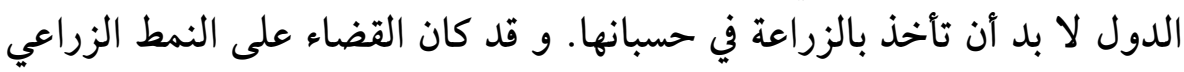

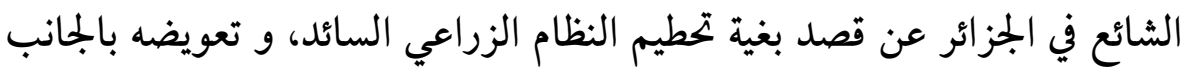

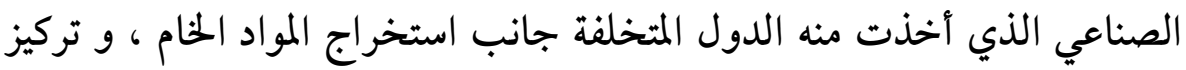

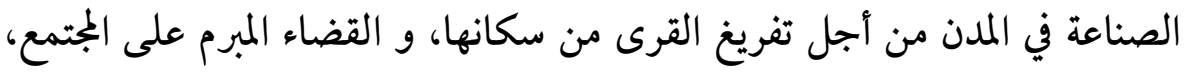

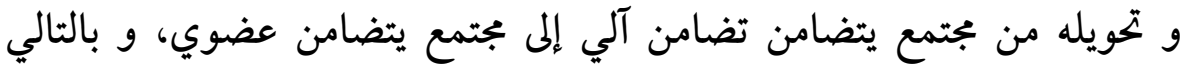
تتفكك شبكة العلاقات الاجتماعية. و بالتالي فقدان التماسك الاجتماعي. نقاعي. و كان اهتمام مالك بن نبي بالفلاحة كمن أجل ضمان لقمة العيش الكريم

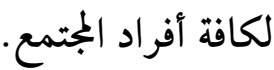




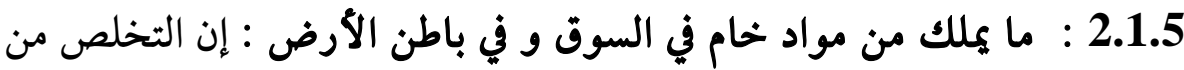

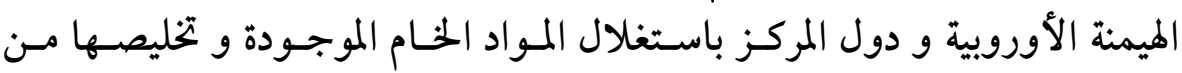

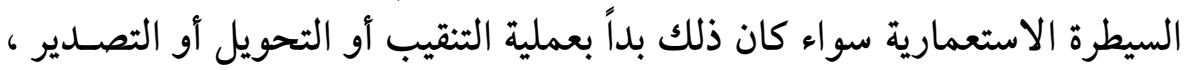

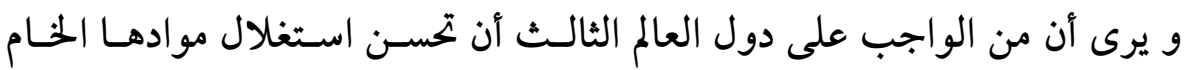

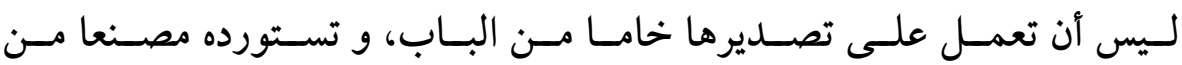

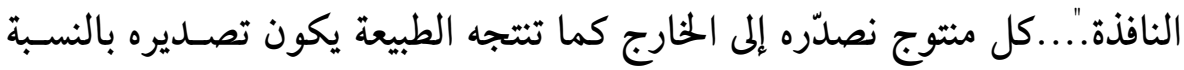

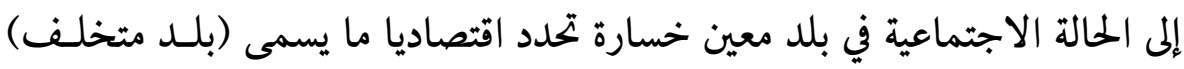

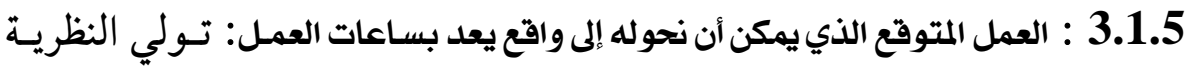

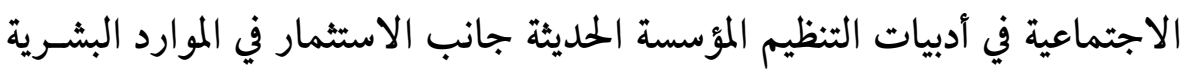

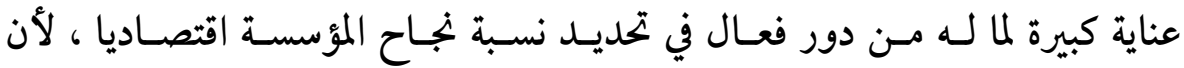

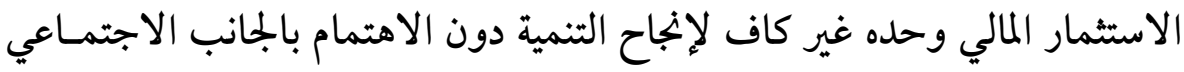

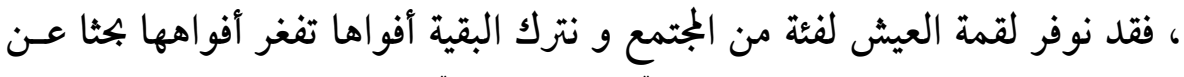

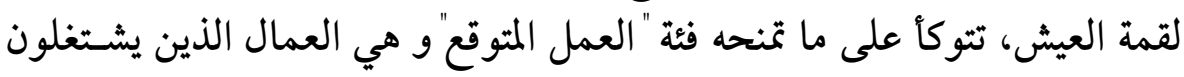

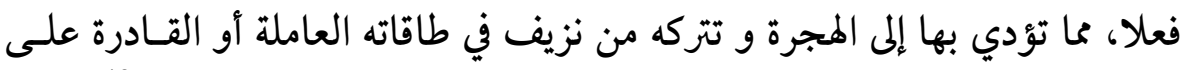

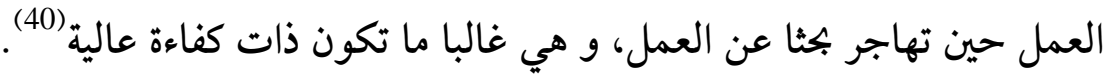

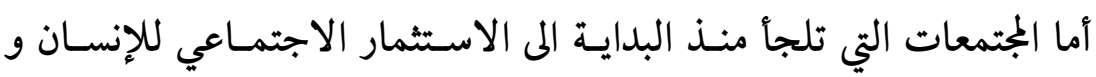

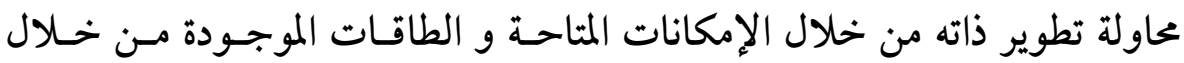

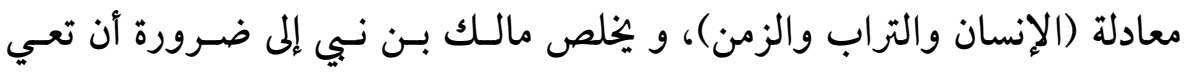

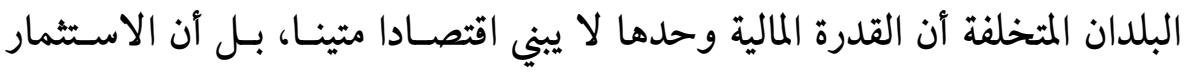

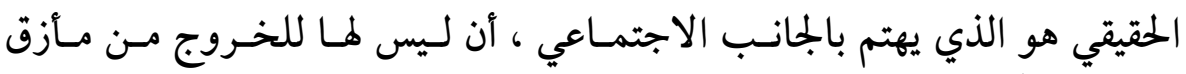

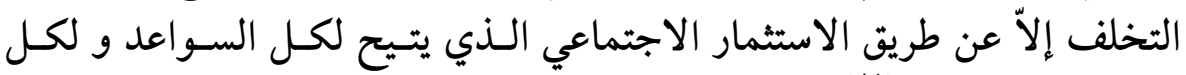

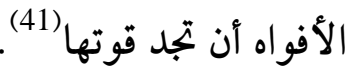


و الاستهالو: أولوية الإنتاج على الاستهلاك: إن معادلتي (الحقوق و الواجبات) و (الإنتاج

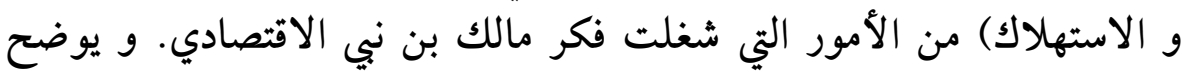
تأثيرهما على نمط و حياة المجتمع من خلالال الصيغة الرياضية التالية:

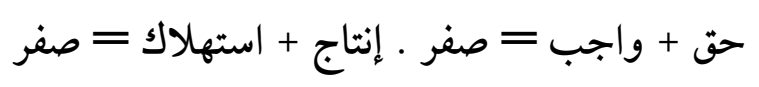

إن التخلص من التخلف و تبعاته السوسيواقتصادية يجب أن يبدأ من نبذ ذهان المئ التهان

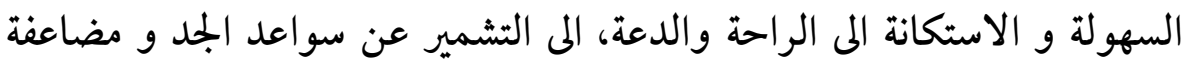

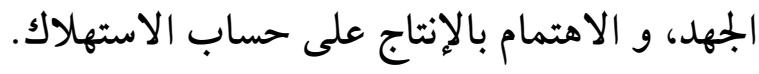
2.5

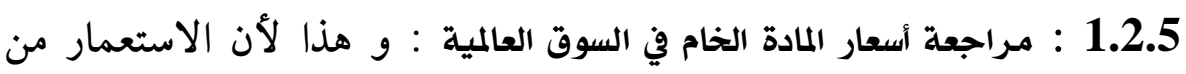

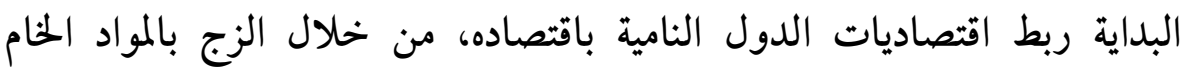

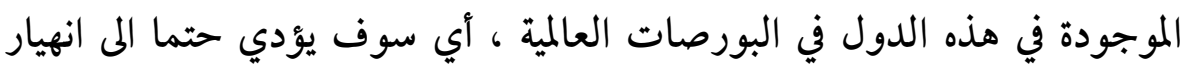

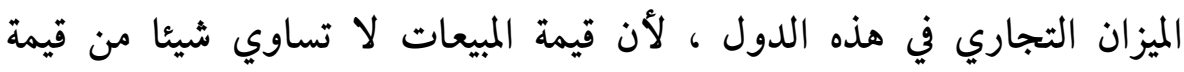

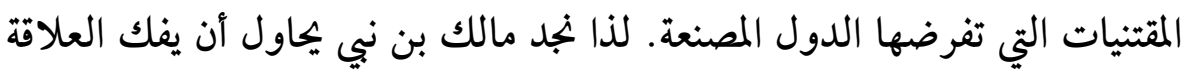

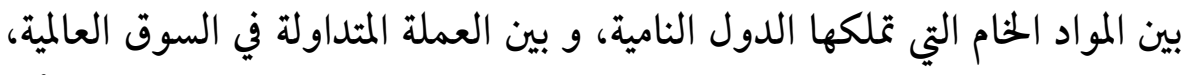

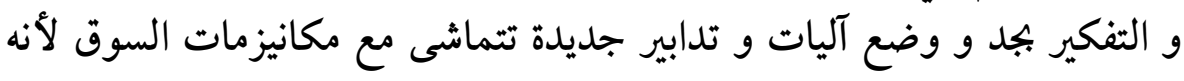

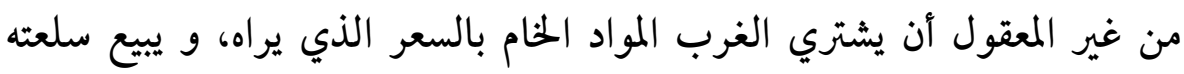

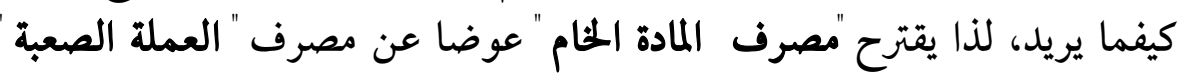

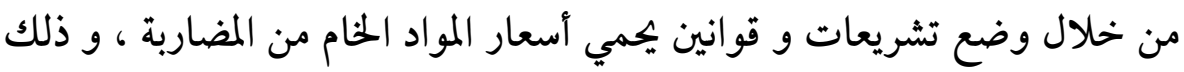

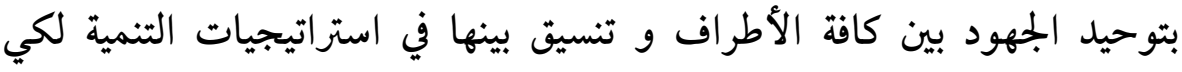

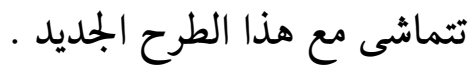
2.2.5 : التكتل الاقتصادي بين دول العالم الثالث: إن التكتل الاقتصادي بين

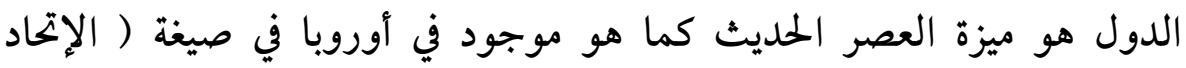

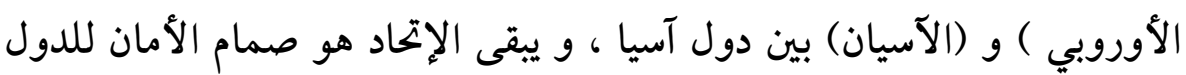

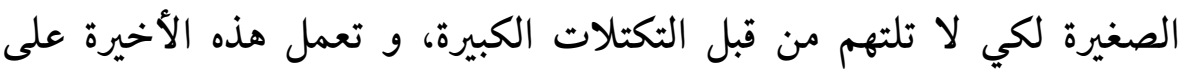


التفرقة بين الدول ، و التعامل معها فرادى من أجل فرض شروطها على الآخر.

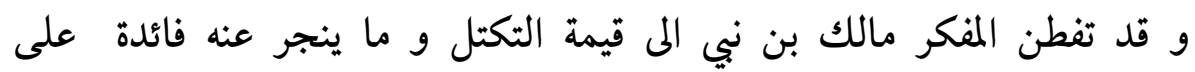

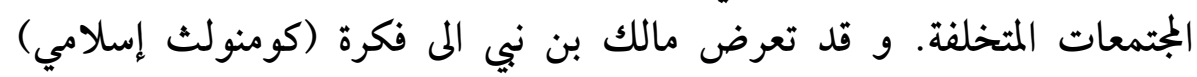

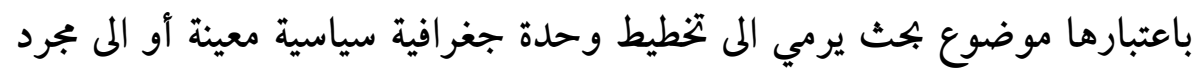

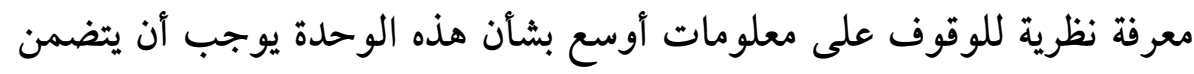

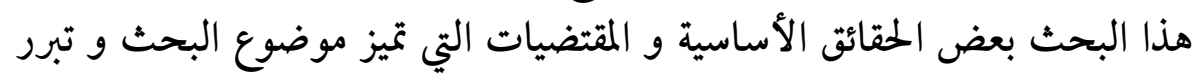
الحل الذي يراد إيجاده.

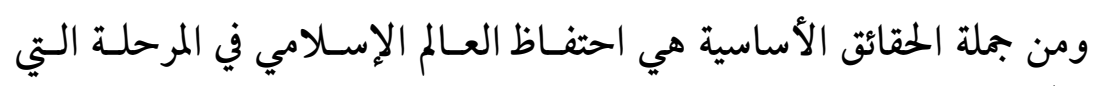

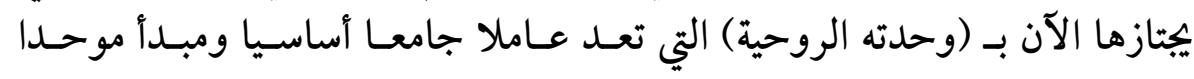

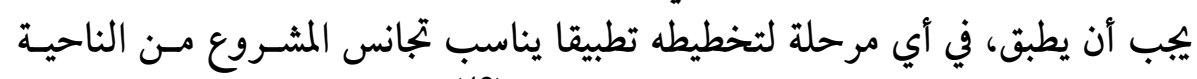
السيكولوجية و تناسق عناصره من الناحية الفنية (42).

لذا يدعو مالك بن نبي الدول العربية الى توحيد الرؤية الاقتصادية تنظيرا

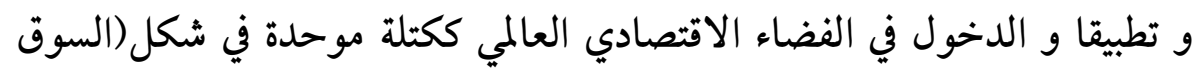
العربية المشتركة ). 
الخاتمة

قدّم مالك بن نبي إسهاما يدخل ضمن إطار الفكر الحضاري عموما،

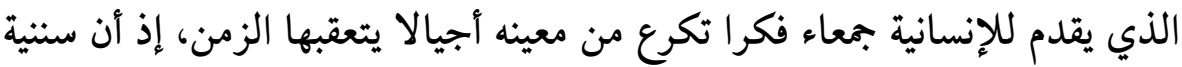

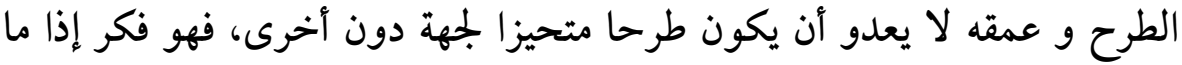

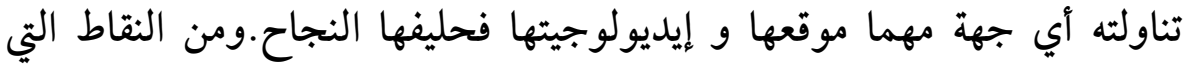
نوجزها في الخلاصة حول عملية التنمية عند إبن ني ما يلي إيلي:

1.الارتباط الوثيق بين التنمية و الحضارة، فالتنمية كما يراها مالك بن نبي هي التياري

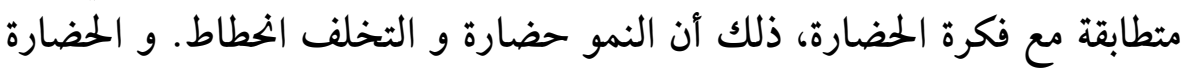

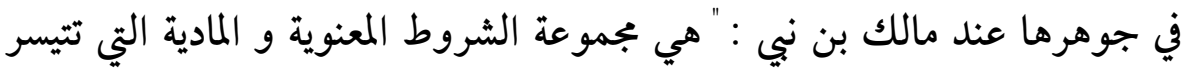

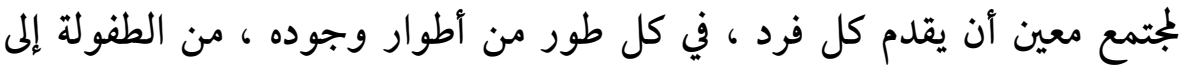

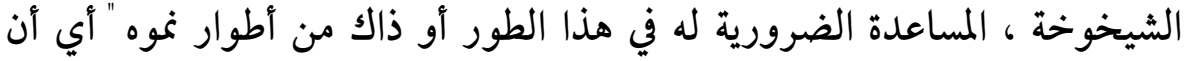

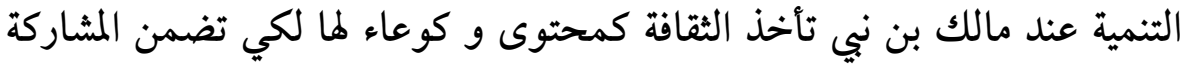

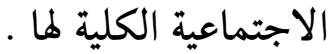

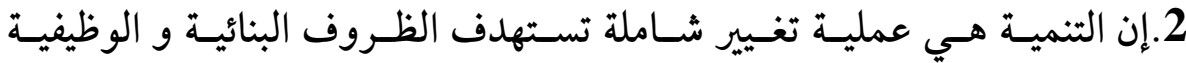

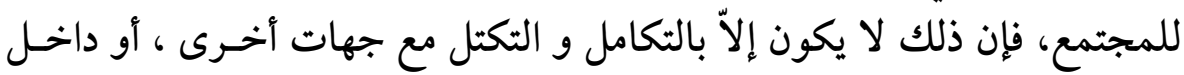

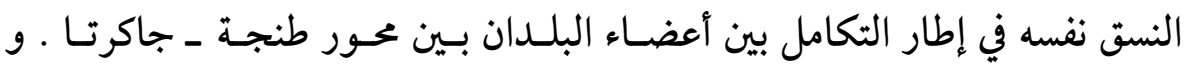

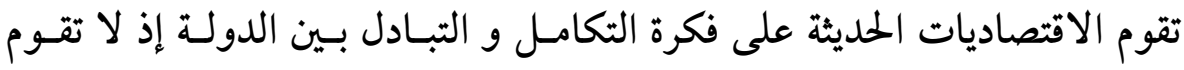

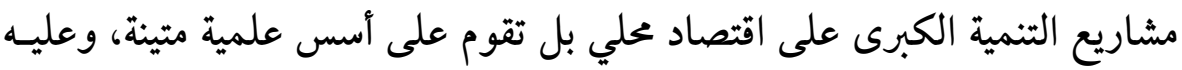

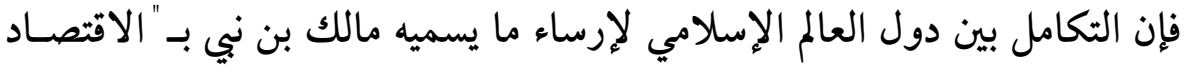

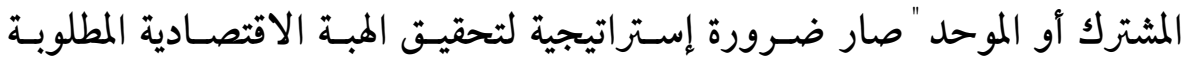

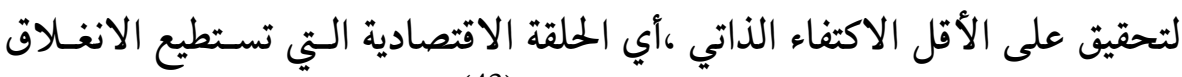

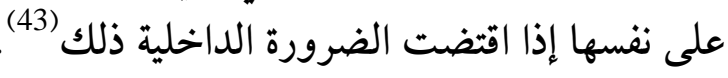

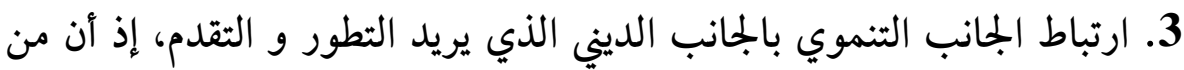

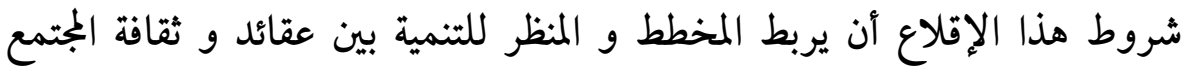


المخطط له، و هي نفس القناعات التي انطلق منها المجتمع السوفياتي و الصيني في

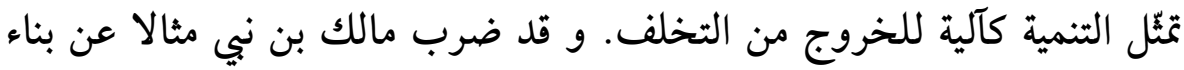

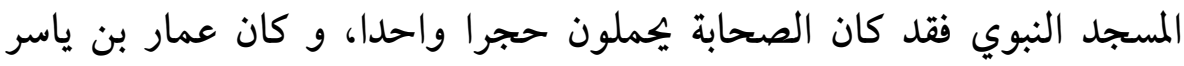

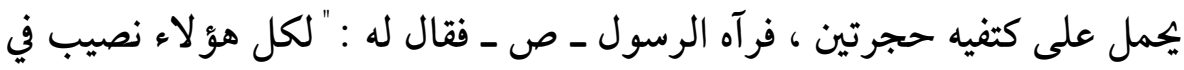

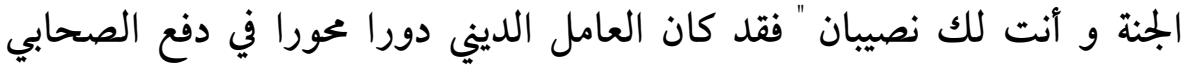
الجليل الى حمل حجرتين مرة واحدة .

و الجانب الروحي و استثمار الطاقة الروحية الكامنة في نفسية الإنسان المسلم

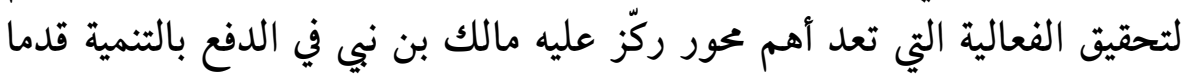

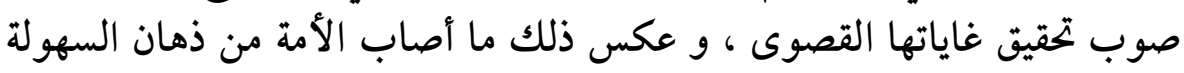

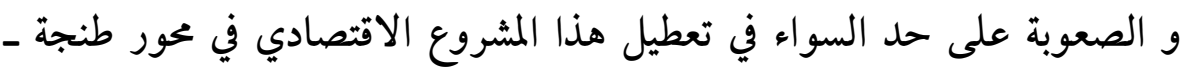

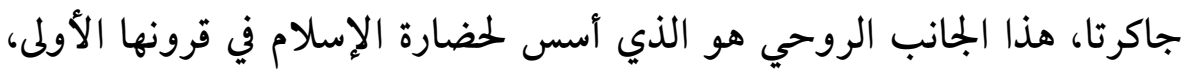

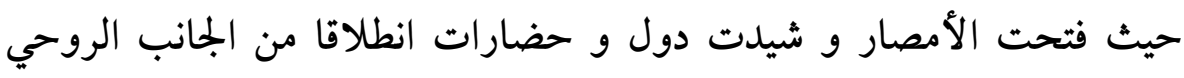
القوي التي تتمتع بها دولة الإسلام.

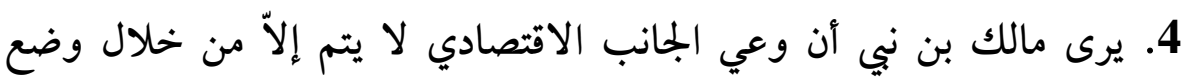

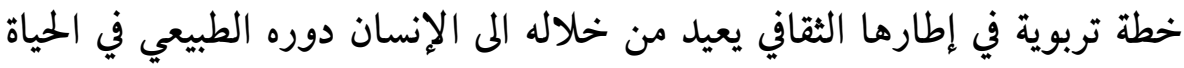

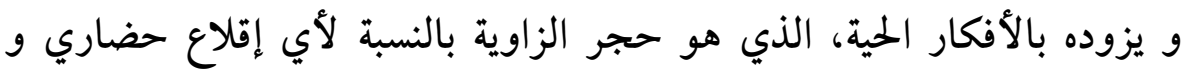

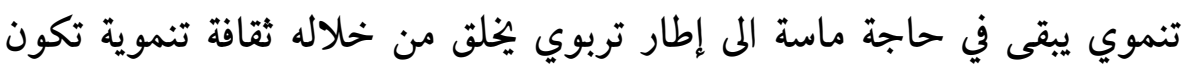

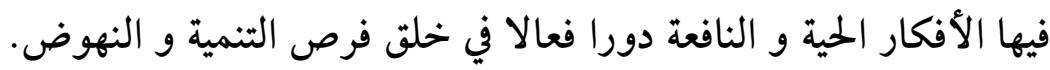
5. الاهتمام بالجانب الفكري إذ يتجه هذا الجانب الى تأطير عملية التنمية بآراء و و

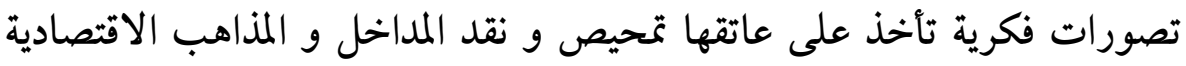

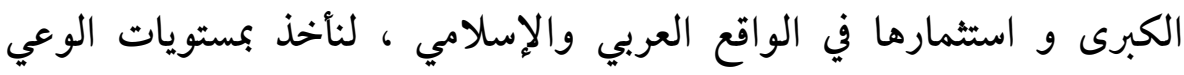

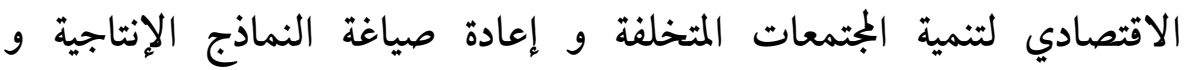

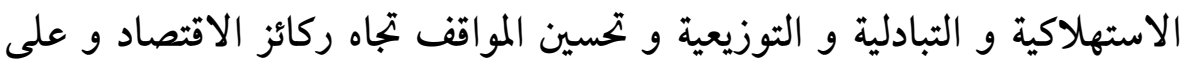
رأسها المال. و يكمن إعادة الوعي التنموي للأمة في النقاط الثالية : 
أ/ التثمين الحقيقي للدور الكميات و الأرقام في تحديد مجال التنمية مقابل

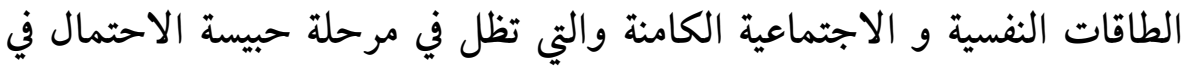
حين تصير عند الإقلاع من عناصر الإمكان الاقتصادي. ب/ إعادة الاعتبار للاستثمار الاجتماعي مقابل الاستثمار المالي و المادي . ج / إعادة الاعتبار لوظيفة الادخار مقابل وظيفة الاستهلاك .

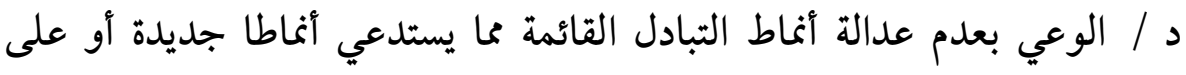

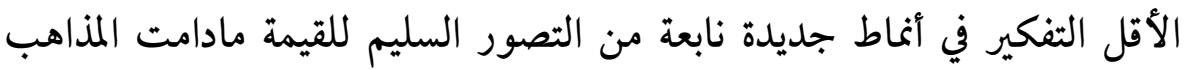
الاقتصادية هي التي تصنع أنماط تبادها.

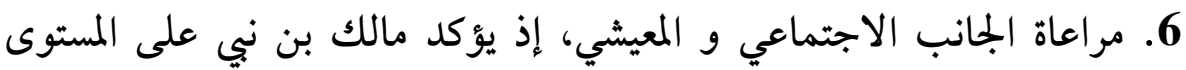

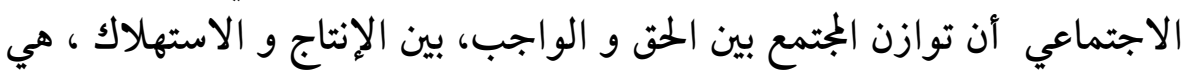

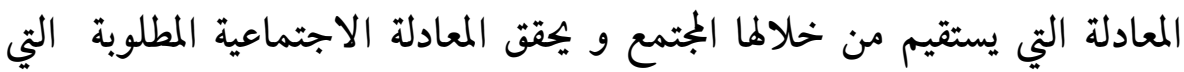

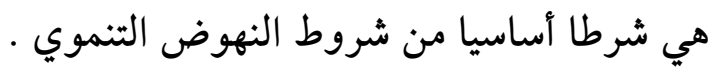

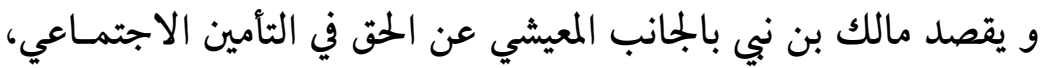

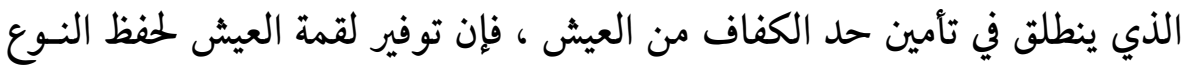

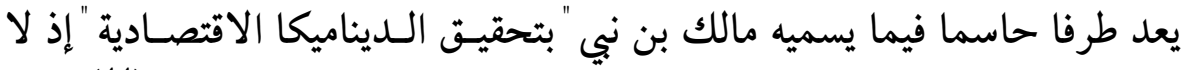

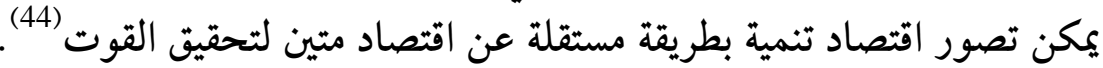
و الشعب الذي يقوم بعملية التنمية هو الشعب الذي يملك الحد الأدنى من قوته لهنه ليفعّل آليات التعمير و سبل النهوض.

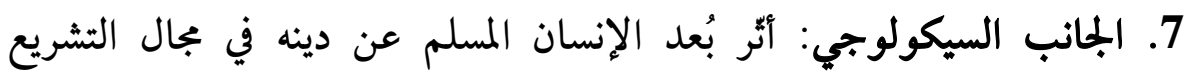

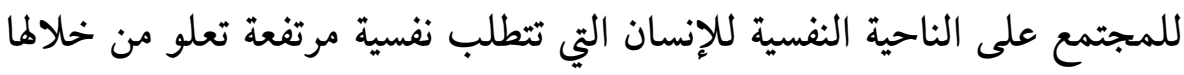

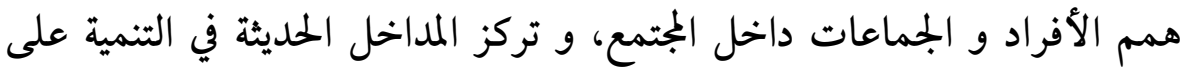

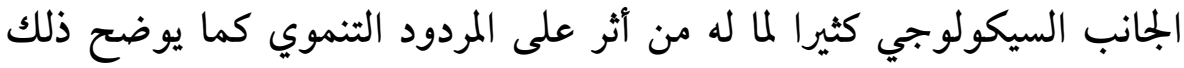

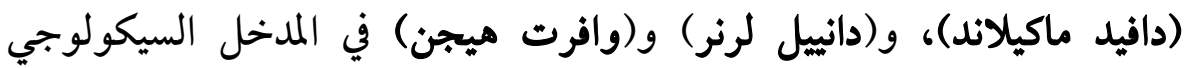


للتنمية الذين يذهبون الى أن درجة الدافعية أو الحاجة الى الإنجاز هي الدعامة

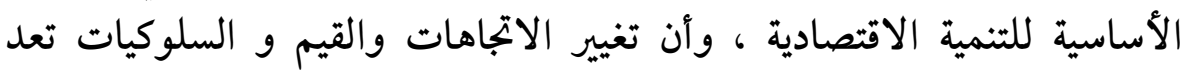
شرطا أساسيا لخلق مجتمع حديث. الأثمادية ، وان.

8 ـ التأكيد على الجانب التخطيطي، فإذا كان التخطيط يعرّف بأنه المواءمة بين ما

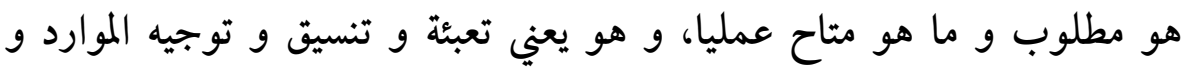
الطاقات و القوى البشرية المتاحة لتحقيق أهداف اقتصادية أو اجتماعية متفق تعنق

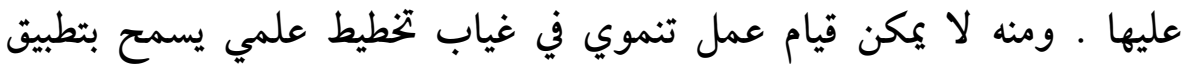

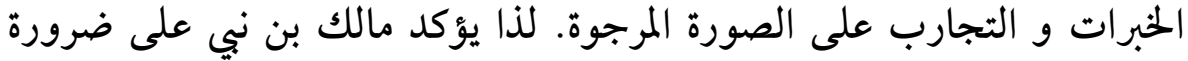

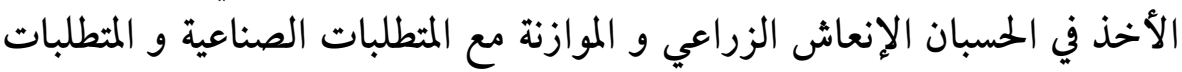

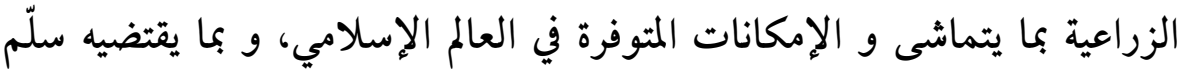

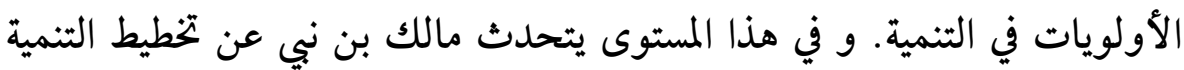

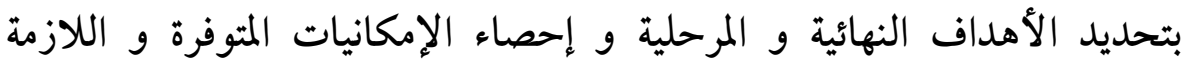

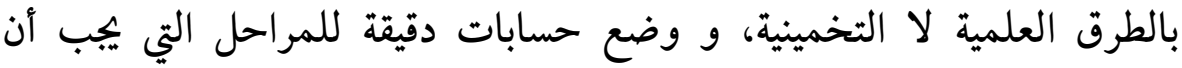
تجتازها المرحلة، و تكييف ظروف الإسكان و المواصلات و التموين لمتطلبات التنمية.

9 ـ البعد الثقافي للتنمية عند مالك بن نبي، و هو طرح جديد بالنسبة لنظرية

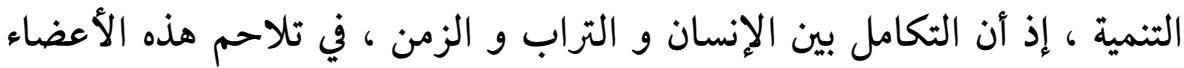

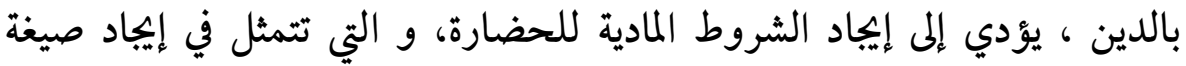

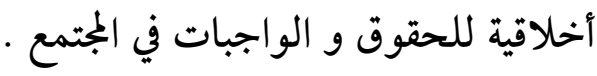

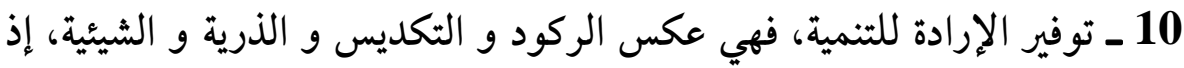

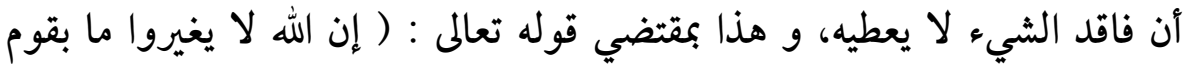

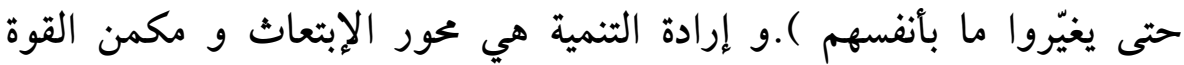

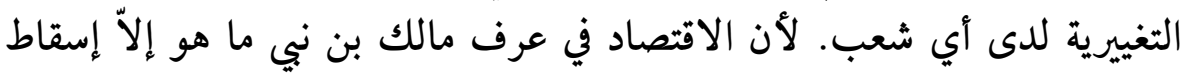


البعد السياسي على نشاط إنساني معين، فبقدر ما تبقى السياسة مرتبطة بمبادئ

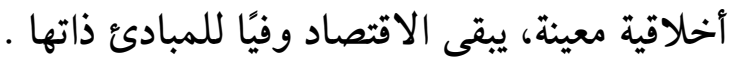

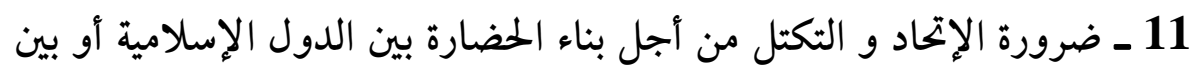

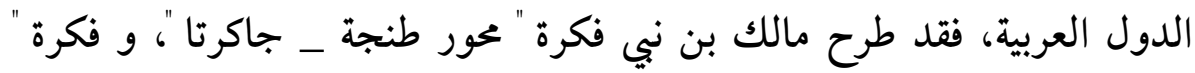

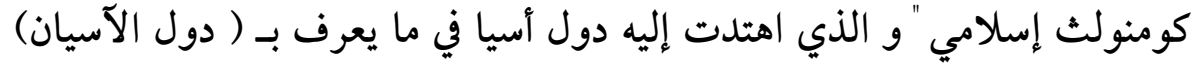

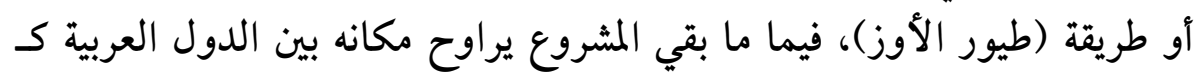

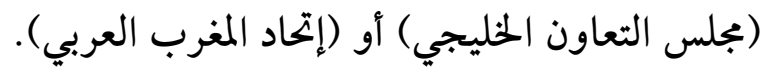




\section{هوامش البحث}

مالك بن نبي، آفاق جزائرية، ط2، مكتبة عمار، مصر، 1964، ص 23. مالك بن نبي، مشكلة الأنكار في العالم الإسلامي، ط2، ترجمة: محمد عبد العظيم علي،

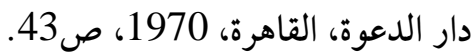

مالك بن نبي، الصراع الفكري في البلاد المستعمرة، دار الفكر، دمشق، سوريا، 1960،

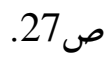

مالك بن نبي، الصراع الفكري في البلاد المستعمرة، مرجع سبق ذكره، ص27. مالك بن نبي، وجهة العالم الإسلامي، ط6، دار الفكر، دمشق، سوريا، 2006، ص 80. مالك بن نبي، المسلم في عالم الاقتصاد،ط3، دار الشروق، بيروت، لبنان،1978، ص36 . مالك بن نبي، مشكلة الثقافة، ط4، دار الفكر ترجمة عبد الصبور شاهين. إشراف ندوة

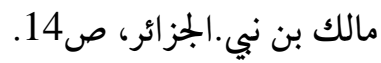

مالك بن نبي، مشكلة الأفكار في العالم الإسلامي، مرجع سبق ذكره، ص 153. مالك بن بي،، تأملات، ط5، دار الفكر، إشراف مالك بن نبي، الجزائر، ص 166. مالك بن نبي، المسلم في عالم الاقتصاد، مرجع سبق ذكره، ص70. مالك بن نبي، المسلم في عالم الاقتصاد، مرجع سبق ذكره، ص74. مالك بن نبي، المسلم في عالم الاقتصاد ، مرجع سبق ذكره، ص74. مالك بن نبي، المسلم في عالم الاقتصاد، مرجع سبق ذكره، ص77.

عبد اللطيف عبادة، صفحات مشرقة من فكر مالك بن نيي، دار الشهاب،باتنة، الجزائر،

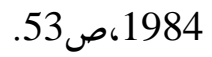

مالك بن نبي، المسلم في عالم الاقتصاد، مرجع سبق ذكره، ص 91. 
مالك بن نبي، المسلم في عالم الاقتصاد، مرجع سبق ذكره، ص96.

مالك بن نبي، ميلاد بجتمع، ط6، دار الفكر، دمشق، سوريا، 2006، 272.

مالك بن نبي، ميلاد مجتمع، مرجع سبق ذكره، ص38.

مالك بن نبي، ميلاد مجتمع، مرجع سبق ذكره، ص42.

كمال التابعي، تغريب العالم الثالث ، دراسة نقدية في علم الاجتماع التنمية ، دار

المعرفة الجامعية، القاهرة، مصر، 1995، صنابع لعابل 151

مالك بن نبي، مشكلة الثقافة،مرجع سبق ذكره، ص67.

مالك بن نبي، بين الرشاد و التيه، ط6، دار الفكر، دمشق، سوريا، 2006، ص60.

مالك بن نبي، تأملات، مرجع سبق ذكره، ص125

مالك بن نبي، شروط النهضة، مرجع سبق ذكره، ص 78.

مالك بن نبي، شروط النهضة، ط6، دار الفكر، دمشق، سوريا، 2006، ص 83.

مالك بن نبي، ميلاد مجتمع، مرجع سبق ذكره، ص101.

مالك بن نبي، شروط النهضة، مرجع سبق ذكره، ص 89.

مالك بن نبي، مشكلة الثقافة، مرجع سبق ذكره، ص 79.

مالك بن بيي، شروط النهضة، مرجع سبق ذكره، ص96.

مالك بن نبي، ميلاد مجتمع، مرجع سبق ذكره، ص صن 105.

مالك بن نبي، ميلاد بجتمع، مرجع سبق ذكره، ص 17.

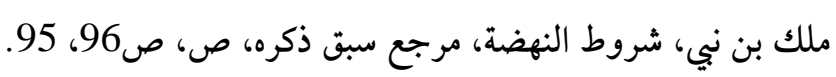

مالك بن نبي، شروط النهضة، مرجع سبق ذكره، ص108.

مالك بن بي،، شروط النهضة، مرجع سبق ذكره، ص112. 
مالك بن نبي، شروط النهضة، مرجع سبق ذكره، ص، ص135، 136.

مالك بن نبي، شروط النهضة، مرجع سبق ذكره، ص، 135. مالك بن نبي، شروط النهضة، مرجع سبق ذكره، ص140.

مالك بن نبي، شروط النهضة، مرجع سبق ذكره، ص، ص140 ، 141.

مالك بن بيي، بين الرشاد و التيه، مرجع سبق ذكره، ص 188.

مالك بن بيي، بين الرشاد و التيه، مرجع سبق ذكره، ص 194.

مالك بن نبي، المسلم في عالم الاقتصاد، مرجع سبق ذكره، ص62 .

مالك بن بي،، فكرة كومنولث إسلامي، ط6، دار الفكر ، دمشق، سوريا، 2006،

مالك بن نبي، المسلم في عالم الاقتصاد، مرجع سبق ذكره، ص107. مالك بن نبي، بين الرشاد و التيه، مرجع سبق ذكره، ص161. 